University of Nebraska - Lincoln DigitalCommons@University of Nebraska - Lincoln

USGS Staff -- Published Research

US Geological Survey

2009

\title{
Possible sources of archaeological maize found in Chaco Canyon and Aztec Ruin, New Mexico
}

Larry Benson

U.S. Geological Survey, great.basin666@gmail.com

J.R. Stein

Navajo Nation Chaco Sites Protection Program

H. E. Taylor

U.S. Geological Survey, hetaylor@usgs.gov

Follow this and additional works at: https:// digitalcommons.unl.edu/usgsstaffpub

Part of the Geology Commons, Oceanography and Atmospheric Sciences and Meteorology Commons, Other Earth Sciences Commons, and the Other Environmental Sciences Commons

Benson, Larry; Stein, J. R.; and Taylor, H. E., "Possible sources of archaeological maize found in Chaco Canyon and Aztec Ruin, New Mexico" (2009). USGS Staff -- Published Research. 748.

https://digitalcommons.unl.edu/usgsstaffpub/748

This Article is brought to you for free and open access by the US Geological Survey at DigitalCommons@University of Nebraska - Lincoln. It has been accepted for inclusion in USGS Staff -- Published Research by an authorized administrator of DigitalCommons@University of Nebraska - Lincoln. 


\title{
Possible sources of archaeological maize found in Chaco Canyon and Aztec Ruin, New Mexico
}

\author{
L.V. Benson ${ }^{\mathrm{a}, *}$, J.R. Stein ${ }^{\mathrm{b}}$, H.E. Taylor ${ }^{\mathrm{a}}$ \\ ${ }^{a}$ U.S. Geological Survey, 3215 Marine Street, Boulder, CO 80303, USA \\ ${ }^{\mathrm{b}}$ Navajo Nation Chaco Sites Protection Program, Navajo Blvd, W008-247, Window Rock, AZ 86515, USA
}

\section{A R T I C L E I N F O}

\section{Article history:}

Received 17 June 2008

Received in revised form 13 August 2008

Accepted 12 September 2008

\section{Keywords:}

Maize

$\mathrm{Sr}$ isotopes

Metals

Four Corners area

Southern Colorado Plateau

Archaeological cobs

\begin{abstract}
A B S T R A C T
Maize played a major role in Chaco's interaction with outlying communities in the southern Colorado Plateau. This paper seeks to determine where archaeological corn cobs brought to Chaco Canyon were grown. Strontium-isotope and trace-metal ratios of 180 soil-water and 18 surface-water sites in the Southern Colorado Plateau have revealed possible source areas for some of 37 archaeological corn cobs from Chaco Canyon and 10 archaeological corn cobs from Aztec Ruin, New Mexico. The most probable source areas for cobs that predate the middle-12th-century drought include several Upper Rio Chaco sites (not including Chaco Canyon). There are many potential source areas for cobs that date to the late A.D. 1100 s and early 1200 s, all of which lie in the eastern part of the study area. Some Athapascan-age cobs have potential source areas in the Totah, Lobo Mesa, and Dinetah regions. One Gallo Cliff Dwelling cob has a strontium-isotope ratio that exceeds all measured soil-water values. Field sites for this cob may exist in association with Paleozoic and Precambrian rocks found $80-90 \mathrm{~km}$ from Chaco Canyon. Potential source areas for most Aztec Ruin cobs (many of which were found in rooms dating to the first half of the 13th-century) appear to be associated with a loess deposit that blankets the Mesa Verde and McElmo Dome regions.
\end{abstract}

Published by Elsevier Ltd.

\section{Introduction}

Chaco Canyon, New Mexico, is located in the heart of the semiarid San Juan Basin (Fig. 1). Between A.D. 850 and 1130, a dozen great houses were constructed in Chaco Canyon with major phases of construction occurring during the Late PII-Classic phase (A.D. 1040-1100) and Early PIII-Late Bonito phase (A.D. 1100-1140) (Lekson, 1984). Many Chacoan-style outlier great houses exhibiting "Bonito-style" architecture also were constructed throughout the San Juan Basin and adjacent areas during the Late Bonito phase (Fig. 1 in Van Dyke, 1999). "Bonito-style" refers to a collection of architectural features including a many-roomed, multiple-storied great house with core-and-veneer masonry, one or more great kivas, and earthworks (Marshall et al., 1982). Most of the great houses were vacated during the middle-12th-century drought with final abandonment of the remaining great houses during the late$13^{\text {th }}$-century drought (Supplementary Figure 1, Benson et al., 2007).

The relation of Chaco to outlier communities has engendered a great deal of theoretical argument which Van Dyke (1999) has recently summarized. The theoretical models differ in the style and

* Corresponding author. USGS, Suite E127, Boulder, CO 80303, USA. Tel.: +1 303 541 3005; fax: +1 3035413084 .

E-mail address: lbenson@usgs.gov (L.V. Benson). degree of control that Chaco exerted over these communities; e.g., Vivian (1989) and Wilcox (1993) have suggested that people from Chaco were directly responsible for the construction of the communities exhibiting Bonito-style architecture and Wilcox (1993) has gone so far as to suggest that Chaco was a military state with a social hierarchy in which economics and religion were centralized. In Wilcox's model, outliers functioned as military headquarters which were established to control the surrounding countryside and to obtain agriculture tribute.

Stein and Lekson (1992) have suggested a model which markedly differs from that suggested by Wilcox (1993) and have argued that the region, which encompassed 11th - and 12th-century communities with Bonito-style architecture (Supplementary Figure 1), was much too large for a coherent "state" to have existed. Instead, they suggested that Bonito-style architecture symbolically linked outlier communities that were otherwise separated by language and ethnicity. In their model, great houses, great kivas, roads, and platform mounds embodied a symbolic ritual landscape that was imitated over much of the Southern Colorado Plateau.

A range of cultural theories exist that, in terms of Chacoan control over outlying communities, lie somewhere in-between the two extremes discussed above. One of them (Judge, 1979) invokes a Chaco-outlier interaction model in which maize figured strongly. In his original theoretical construction, Chaco Canyon acted as a redistribution center for subsistence goods. Judge (1989) later 


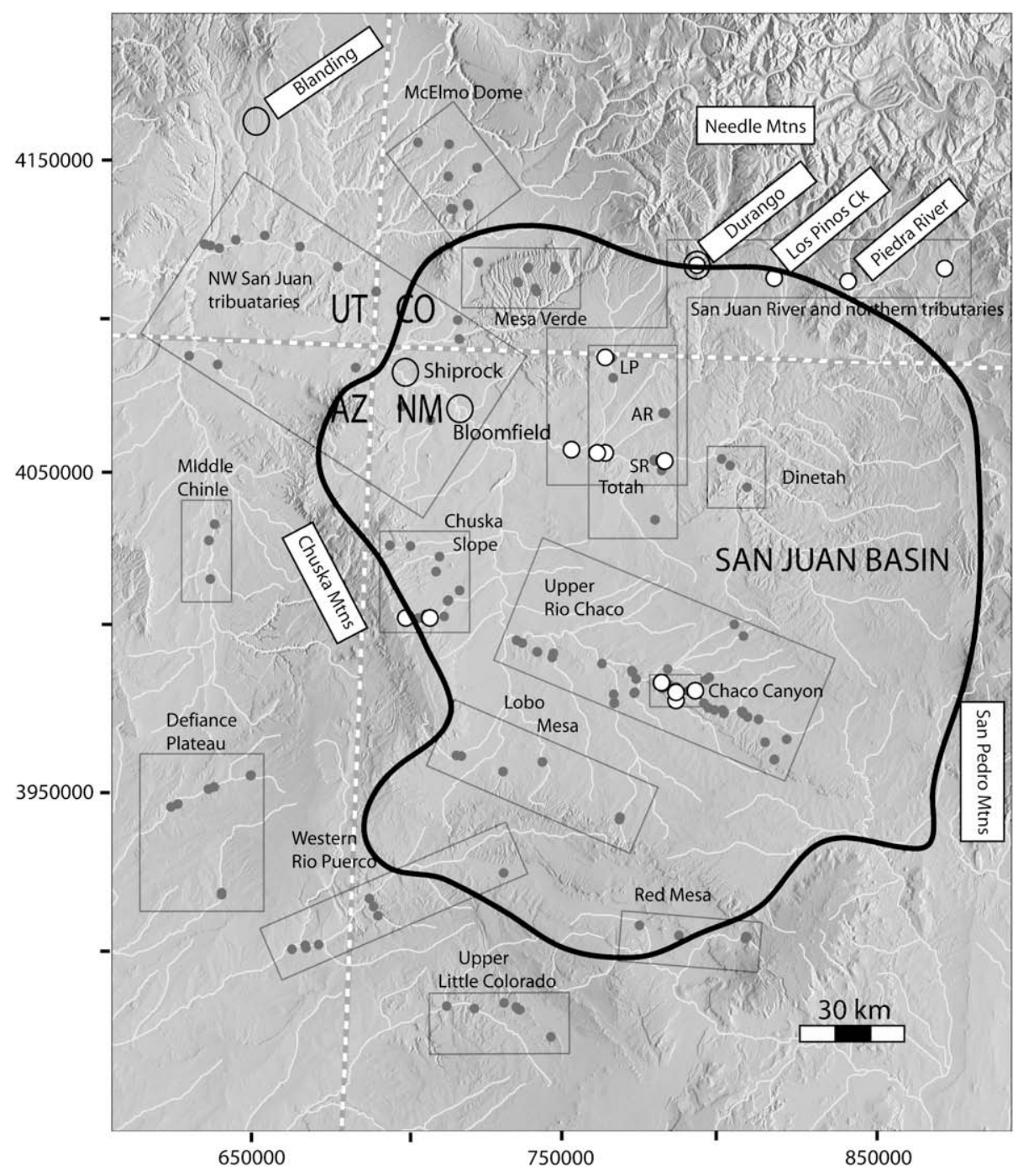

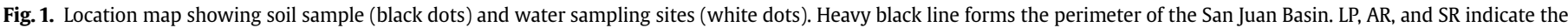

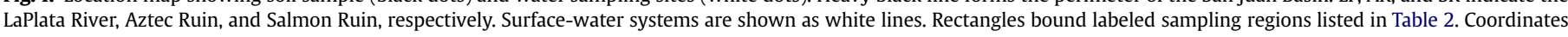
referenced to NAD 27 datum.

modified the redistribution model such that formal pilgrimages to Chaco developed during the Classic Bonito phase wherein "goods were transported to Chaco from outlying locations and consumed under a ritual metaphor."

We will probably never know the exact relation of Chaco to outlier great house communities. However, maize was involved in Chaco's interaction with the outliers, whether it took place under the auspices of a military state, whether Chaco acted as a benevolent redistribution center, or whether Chaco was a place of power that was visited and celebrated during "pilgrimage fairs". The importation of maize thus offers a measure of cultural exchange between Chaco and the outlying communities.

This paper represents the fourth in a series of studies (Benson et al., 2003, 2006, 2008) that seek to determine the source(s) of archaeological corn cobs (hereafter referred to as cobs) found in Chaco Canyon. In the first study, Benson et al. (2003) created synthetic soil-waters by leaching agricultural soils with acetic acid and showed that the isotope ratios $\left({ }^{87} \mathrm{Sr} /{ }^{86} \mathrm{Sr}\right)$ of strontium $(\mathrm{Sr})$ in the synthetic soil-waters were identical to the ${ }^{87} \mathrm{Sr} /{ }^{86} \mathrm{Sr}$ ratios of $\mathrm{Sr}$ in cobs produced from those soils. They also compared the ${ }^{87} \mathrm{Sr} /{ }^{86} \mathrm{Sr}$ ratios of seven archaeological cobs from Pueblo Bonito with three candidate source areas: the Chuska slope (four soil sites), Salmon
Ruin (two sites) and Aztec Ruin (three soil sites) (both located in the Totah region), and Chaco Canyon itself (10 soil sites). The data suggested that the most likely source area for six of the cobs was the Chuska slope and the most likely source of the seventh cob was the Totah region.

In the second study, Benson et al. (2006) increased the sampling density of soils in the three areas, including the Chuska slope (14 soil sites), Salmon Ruin (five soil sites), Aztec Ruin (six soil sites), and Chaco Canyon (22 soil sites). The new Totah-area samples came from the Animas and San Juan river floodplains and most of the new samples from Chaco Canyon came from side-valley tributaries. In addition, 12 new side-tributary and floodplain sites downstream from Chaco Canyon and two new upstream sites were sampled. One sample also was collected from beside the Escavada Wash north of the canyon. The ${ }^{87} \mathrm{Sr} /{ }^{86} \mathrm{Sr}$ ratios of synthetic soil-waters produced in this study showed that several downstream Rio Chaco side-tributary sites between the canyon and the Big Bend of the Rio Chaco also could have been the source(s) of six of the Pueblo Bonito cobs.

In the third study, Benson et al. (2008) sought to refine tracemetal distribution coefficients that describe the systematic partitioning of some metal pairs from soil-water into a cob. According to these authors "The use of the distribution coefficient accounts for 
Table 1

Radiocarbon and ${ }^{87} \mathrm{Sr} /{ }^{86} \mathrm{Sr}$ data for archaeological cobs from Aztec Ruin and Chaco Canyon

\begin{tabular}{|c|c|c|c|c|c|c|c|c|c|c|c|c|c|}
\hline Site no. & Site name & ${ }^{14} \mathrm{C}$ Lab no. & $\delta^{13} \mathrm{C}(\%)$ & $\begin{array}{l}{ }^{14} \mathrm{C} \text { age } \\
\text { (yr BP) }\end{array}$ & $\begin{array}{l}{ }^{14} \mathrm{C} \text { error } \\
\text { (yr) }\end{array}$ & $\begin{array}{l}\text { Cal. age midpt. } \\
(1 \sigma \mathrm{AD})\end{array}$ & $\begin{array}{l}\text { Cal. age range } \\
(1 \sigma \mathrm{yr})\end{array}$ & $\begin{array}{l}\text { Range prob. } \\
\text { (fraction) }\end{array}$ & $\begin{array}{l}\text { Cal. age midpt. } \\
(2 \sigma \mathrm{AD})\end{array}$ & $\begin{array}{l}\text { Cal. age range } \\
(2 \sigma \mathrm{yr})\end{array}$ & $\begin{array}{l}\text { Range prob. } \\
\text { (fraction) }\end{array}$ & $\left.{ }^{87} \mathrm{Sr}\right|^{86} \mathrm{Sr}$ & $\begin{array}{l}{ }^{87} \mathrm{Sr} /{ }^{86} \mathrm{Sr} \text { error } \\
(2 \sigma)\end{array}$ \\
\hline \multicolumn{14}{|l|}{ Aztec Ruin Cobs } \\
\hline AZRU 533A & East Room P15 & & & & & & & & & & & 0.709848 & 0.000011 \\
\hline AZRU 533B & East Room P15 & & & & & & & & & & & 0.710119 & 0.000010 \\
\hline AZRU 1052 & East Room 11 & & & & & & & & & & & 0.710166 & 0.000034 \\
\hline AZRU 1057 & East Room 14 & & & & & & & & & & & 0.710312 & 0.000019 \\
\hline AZRU 3853 & East Room 12 & & & & & & & & & & & 0.709801 & 0.000015 \\
\hline AZRU 3921 & West Room 224 & & & & & & & & & & & 0.709791 & 0.000012 \\
\hline AZRU 9341 & West Room 225 & & & & & & & & & & & 0.710062 & 0.000012 \\
\hline AZRU 9438 & West Room 225 & & & & & & & & & & & 0.709705 & 0.000016 \\
\hline AZRU 9651 & West Room 225 & & & & & & & & & & & 0.709977 & 0.000012 \\
\hline AZRU 11091 & West Room 186 & & & & & & & & & & & 0.709694 & 0.000015 \\
\hline \multicolumn{14}{|l|}{ Pueblo Bonito Cobs } \\
\hline H10648 & Pueblo Bonito Room 170 & Beta- 188110 & -8.8 & 1020 & 40 & 1005 & $974-1040$ & 0.99 & 998 & $944-1052$ & 0.79 & 0.709892 & 0.000016 \\
\hline $\mathrm{H} 242 / 244 \mathrm{~A}$ & Pueblo Bonito Room 3 & Beta-188111 & -8.9 & 1050 & 40 & 996 & $969-1023$ & 0.90 & 963 & $892-1034$ & 1.00 & 0.709319 & 0.000016 \\
\hline $\mathrm{H} 242 / 244 \mathrm{~B}$ & Pueblo Bonito Room 3 & Beta-198921 & & 1060 & 40 & 994 & $967-1020$ & 0.83 & 960 & $893-1026$ & 1.00 & 0.709475 & 0.000042 \\
\hline $\mathrm{H} 254 / 258 \mathrm{~A}$ & Pueblo Bonito Room 3 & Beta-188112 & -9.6 & 890 & 40 & 1181 & $1151-1211$ & 0.56 & 1127 & $1035-1219$ & 1.00 & 0.709394 & 0.000010 \\
\hline H254/258B & Pueblo Bonito Room 3 & Beta- 188113 & -10.1 & 1080 & 40 & 972 & 947-998 & 0.64 & 955 & 889-1021 & 1.00 & 0.709225 & 0.000018 \\
\hline H254/258C & Pueblo Bonito Room 3 & Beta-198920 & & 1190 & 40 & 832 & 779-886 & 1.00 & 834 & $765-902$ & 0.82 & 0.709280 & 0.000014 \\
\hline H7673 & Pueblo Bonito Room 92 & Beta-181114 & -9.9 & 830 & 50 & 1214 & $1169-1258$ & 1.00 & 1213 & $1148-1278$ & 0.87 & 0.709328 & 0.000011 \\
\hline \multicolumn{14}{|l|}{ Other Chaco Canyon Cobs } \\
\hline CHCU2081-1 & Una Vida & & & & & & & & & & & 0.709401 & 0.000009 \\
\hline CHCU2685-1 & Cliff Face & UCIAMS\#23973 & -9.9 & 170 & 20 & 1758 & $1736-1780$ & 0.62 & 1756 & $1728-1785$ & 0.50 & 0.713553 & 0.000013 \\
\hline CHCU2685-2 & Cliff Face & UCIAMS\#23974 & -10.2 & 360 & 20 & 1494 & $1470-1519$ & 0.64 & 1490 & $1455-1524$ & 0.54 & 0.710082 & 0.000015 \\
\hline CHCU32288-1 & Chetro Ketl Room 92 & UCIAMS\#23975 & -9.3 & 880 & 20 & 1183 & $1156-1210$ & 1.00 & 1184 & $1151-1217$ & 0.77 & 0.709523 & 0.000014 \\
\hline CHCU32288-2 & Chetro Ketl Room 92 & UCIAMS\#23976 & -9.1 & 870 & 20 & 1186 & $1163-1208$ & 1.00 & 1186 & $1153-1220$ & 0.91 & 0.709350 & 0.000009 \\
\hline CHCU32289-1 & Chetro Ketl Room 92 & UCIAMS\#23977 & -9.5 & 870 & 20 & 1186 & $1163-1208$ & 1.00 & 1186 & $1153-1220$ & 0.91 & 0.709547 & 0.000015 \\
\hline CHCU32299-1 & Kin Kletso & UCIAMS\#23978 & -9.4 & 805 & 20 & 1238 & $1222-1254$ & 1.00 & 1240 & $1209-1270$ & 1.00 & 0.710747 & 0.000010 \\
\hline CHCU32999-1 & Kin Kletso & UCIAMS\#23979 & -10.1 & 850 & 25 & 1194 & $1170-1218$ & 1.00 & 1206 & $1155-1258$ & 0.99 & 0.709258 & 0.000015 \\
\hline CHCU32999-2 & Kin Kletso & UCIAMS\#23980 & -9.7 & 880 & 20 & 1183 & $1156-1210$ & 1.00 & 1184 & $1151-1217$ & 0.77 & 0.709280 & 0.000012 \\
\hline CHCU43684-1 & Gallo Cliff Dwelling & UCIAMS\#23981 & -8.8 & 845 & 25 & 1195 & $1170-1220$ & 1.00 & 1208 & $1158-1258$ & 1.00 & 0.710880 & 0.000014 \\
\hline CHCU43684-2 & Gallo Cliff Dwelling & UCIAMS\#23983 & -9.6 & 845 & 20 & 1198 & $1177-1219$ & 1.00 & 1194 & $1161-1228$ & 0.93 & 0.711062 & 0.000014 \\
\hline CHCU43684-3 & Gallo Cliff Dwelling & UCIAMS\#23984 & -10.6 & 850 & 25 & 1194 & $1170-1218$ & 1.00 & 1206 & $1155-1258$ & 0.99 & 0.709638 & 0.000011 \\
\hline CHCU43684-4 & Gallo Cliff Dwelling & UCIAMS\#23985 & -10.5 & 915 & 25 & 1070 & 1045-1095 & 0.60 & 1107 & $1032-1182$ & 1.00 & 0.709770 & 0.000011 \\
\hline CHCU43684-5 & Gallo Cliff Dwelling & UCIAMS\#23986 & -10.1 & 880 & 20 & 1183 & $1156-1210$ & 1.00 & 1184 & $1151-1217$ & 0.77 & 0.709586 & 0.000015 \\
\hline CHCU43684-6 & Gallo Cliff Dwelling & UCIAMS\#23987 & -9.6 & 870 & 25 & 1186 & $1160-1212$ & 1.00 & 1186 & $1149-1224$ & 0.82 & 0.709412 & 0.000011 \\
\hline CHCU43684-7 & Gallo Cliff Dwelling & UCIAMS\#23989 & -10.0 & 875 & 25 & 1184 & $1155-1214$ & 1.00 & 1184 & $1148-1221$ & 0.76 & 0.710244 & 0.000010 \\
\hline CHCU43684-8 & Gallo Cliff Dwelling & UCIAMS\#23990 & -10.0 & 880 & 25 & 1184 & $1155-1212$ & 0.90 & 1183 & $1147-1219$ & 0.69 & 0.709759 & 0.000011 \\
\hline CHCU43684-9 & Gallo Cliff Dwelling & UCIAMS\#23991 & -9.4 & 855 & 30 & 1190 & $1162-1219$ & 1.00 & 1206 & $1152-1259$ & 0.91 & 0.710010 & 0.000014 \\
\hline CHCU43684-10 & Gallo Cliff Dwelling & UCIAMS\#23992 & -10.2 & 865 & 20 & 1188 & 1167-1209 & 1.00 & 1188 & $1154-1221$ & 0.95 & 0.709961 & 0.000014 \\
\hline CHCU43684-11 & Gallo Cliff Dwelling & UCIAMS\#23994 & -9.8 & 865 & 20 & 1188 & 1167-1209 & 1.00 & 1188 & $1154-1221$ & 0.95 & 0.710270 & 0.000013 \\
\hline CHCU43684-12 & Gallo Cliff Dwelling & UCIAMS\#23995 & -10.1 & 880 & 20 & 1183 & $1156-1210$ & 1.00 & 1184 & $1151-1217$ & 0.77 & 0.710198 & 0.000010 \\
\hline CHCU43684-13 & Gallo Cliff Dwelling & UCIAMS\#23996 & -9.1 & 875 & 20 & 1184 & $1160-1208$ & 1.00 & 1185 & $1152-1218$ & 0.85 & 0.711580 & 0.000013 \\
\hline CHCU43684-14 & Gallo Cliff Dwelling & UCIAMS\#23997 & -8.8 & 870 & 20 & 1186 & 1163-1208 & 1.00 & 1186 & $1153-1220$ & 0.91 & 0.711575 & 0.000015 \\
\hline CHCU43684-15 & Gallo Cliff Dwelling & UCIAMS\#23998 & -9.5 & 875 & 20 & 1184 & $1160-1208$ & 1.00 & 1185 & $1152-1218$ & 0.85 & 0.710143 & 0.000015 \\
\hline CHCU43684-16 & Gallo Cliff Dwelling & UCIAMS\#23999 & -8.9 & 885 & 20 & 1182 & $1155-1208$ & 0.86 & 1182 & $1149-1216$ & 0.68 & 0.710094 & 0.000013 \\
\hline CHCU50553-1 & Cliff Face Room 29mC499 & UCIAMS\#24000 & -8.2 & 125 & 25 & 1858 & $1832-1885$ & 0.44 & 1847 & $1800-1894$ & 0.50 & 0.710769 & 0.000022 \\
\hline CHCU50553-2 & Cliff Face Room 29mC499 & UCIAMS\#24001 & -9.0 & 115 & 20 & 1859 & $1832-1886$ & 0.55 & 1850 & 1805-1895 & 0.57 & 0.711302 & 0.000014 \\
\hline CHCU57-1 & BC 236 & UCIAMS\#23972 & -9.7 & 835 & 25 & 1201 & $1176-1226$ & 0.91 & 1211 & $1164-1258$ & 1.00 & 0.710165 & 0.000014 \\
\hline Site\#1 Chaco E cob\#1 & 29SJ 176, LA 40176 & UCIAMS\#24002 & -8.6 & 155 & 20 & 1754 & 1730-1777 & 0.55 & 1754 & $1725-1782$ & 0.43 & 0.710134 & 0.000011 \\
\hline Site\#1 Chaco E cob\#2 & 29SJ 176, LA 40176 & UCIAMS\#24003 & -9.0 & 165 & 20 & 1756 & $1735-1778$ & 0.61 & 1756 & $1727-1784$ & 0.49 & 0.709839 & 0.000016 \\
\hline
\end{tabular}

Bold site numbers and names indicate samples which are Sr contaminated; ${ }^{14} \mathrm{C}$ dates in italics and bold indicate Athapascan-age samples.

Pueblo Bonito cob dates taken from Cordell et al. (2008). 
the bioavailability of chemical species (they are part of the soilwater solution), and the use of a metal ratio negates the effect of changes in soil-water concentration on the concentrations of individual dissolved trace-metals. However, $K_{\mathrm{D}}$ is not constant for all metal ratios. Metal pairs that contain a trace nutrient that the plant prefers to incorporate or a trace-metal that the plant prefers to exclude (e.g. lead) may exhibit widely varying $K_{\mathrm{D}}$ values. In addition to being plant-species dependent, the $K_{\mathrm{D}}$ value also depends on the set of environmental conditions under which the plant grew; e.g., moisture or nutrient stress. $K_{D}$ values will tend to be relatively constant for element pairs that have similar chemical properties if those properties are neither essential nor harmful to the plant."

Using an extremely limited data set, Benson et al. (2003) had earlier suggested that three metal pairs $(\mathrm{Ba} / \mathrm{Sr}, \mathrm{Mg} / \mathrm{Sr}, \mathrm{Y} / \mathrm{Yb})$ might obey the relation

$K_{\mathrm{D}}\left(C_{\mathrm{TE} 1} / C_{\mathrm{TE} 2}\right)_{\text {Soil water }}=\left(C_{\mathrm{TE} 1} / C_{\mathrm{TE} 2}\right)_{\mathrm{Cob}}$

where $C_{\mathrm{TE} 1} / C_{\mathrm{TE} 2}$ is the concentration ( $\mu \mathrm{g}$ element/g dry-weight soil) ratio of trace-metals 1 and 2 and $K_{\mathrm{D}}$ indicates the distribution coefficient. If this was true, then those metal pairs could be used in the same manner as ${ }^{87} \mathrm{Sr} /{ }^{86} \mathrm{Sr}$ to further define maize source areas.

In order to refine the results of earlier studies, Benson et al. (2008) selected two cobs from each of 10 plants from each of five Native American landraces grown out at New Mexico State University's Agricultural Science Center, Farmington, New Mexico (Adams et al., 2006). Soils were obtained from both sides of the corn row at the base of each stalk at depths centered on 35 and $70 \mathrm{~cm}$. After a series of pretreatments (see methods section in Benson et al., 2008), multitrace-metal determinations were performed on the cobs and the synthetic soil-waters, using inductively coupled plasma-massspectrometry (ICP-MS) and ICP emission spectrometry (ICP-AES). Using all paired combinations of the 51 measured trace-metals, it was determined that four metal pairs $(\mathrm{Ba} / \mathrm{Sr}, \mathrm{Ba} / \mathrm{Mn}, \mathrm{Ca} / \mathrm{Sr}$, and $\mathrm{K} / \mathrm{Rb}$ ) exhibited systematic distribution coefficients (standard deviation of a metal pair $K_{\mathrm{D}}$ for a particular landrace was $\leq 33 \%$ of its mean value) between soil-waters and all cob types.

This paper represents a progress report with regard to our maize-sourcing research. The objective of this study was to determine the source(s) of 37 archaeological cobs found in Chaco Canyon in the hope that such data will help better decipher Chaco's interaction with other communities within the greater San Juan Basin between A.D. 850 and 1300. In the present study, we have expanded our sampling to include soils from 14 regions and 180 sites within the San Juan Basin and adjacent areas (Fig. 1); we also have analyzed 30 additional archaeological cobs. Methods employed in this study, as well as trace-metal and ${ }^{87} \mathrm{Sr} /{ }^{86} \mathrm{Sr}$ data sets resulting from this study, can be found in supplementary online material, which includes Supplementary Tables 1-5.

\section{Results}

\subsection{Radiocarbon ages of the archaeological cobs}

The ${ }^{14} \mathrm{C}$ ages of the Aztec West Ruin and Pueblo Bonito cobs that were analyzed for ${ }^{87} \mathrm{Sr} /{ }^{86} \mathrm{Sr}$ and trace-metals were not determined by Benson et al. (2003); however, Cordell et al. (2008) have recently dated seven of the Pueblo Bonito cobs and those dates have been included in Table 1. Six of the Aztec Ruin cobs (AZRU 11091, 533A, 533B, 1057, 3853 and 1052) are associated with room timbercutting dates of, respectively, A.D. 1114, 1215, 1215, 1240, 1241, and 1241. Thus, the oldest cob was probably deposited prior to the middle-12th-century drought and the remaining cobs were deposited after the middle-12th-century drought, but prior to the late-13th-century drought.
For the present study, we were able to obtain ${ }^{14} \mathrm{C}$ dates on 29 of 30 archaeological cobs from six archaeological contexts (Cliff Face, Chetro Ketl, Kin Kletso, Gallo Cliff Dwelling, BC 236, and 29SJ 176/LA 40176; Table 1). One cob from Una Vida did not survive the acidbase treatment at the Keck Carbon Cycle AMS Facility. Most (16) of the new cobs came from a trash area in Gallo Cliff Dwelling (CHCU 43684) in which 256 cobs had been discarded.

The cobs exhibit a wide range of calibrated dates with the six youngest cobs presumably being Athapascan in origin (Fig. 2A). The Athapascan-age cobs came from three caches in and east of Downtown Chaco; e.g., the 29SJ176 samples came from a crushed "storage" room $0.5 \mathrm{~km}$ west of Sheep Camp Canyon. Calibrations were performed using CALIB 5.0 (Stuiver et al., 2005). The remaining 25 cobs range in age from A.D.1070 to 1240 (calibrated ages mentioned here are midpoints of 1-sigma age ranges). However, many of the cobs (21) have essentially the same age
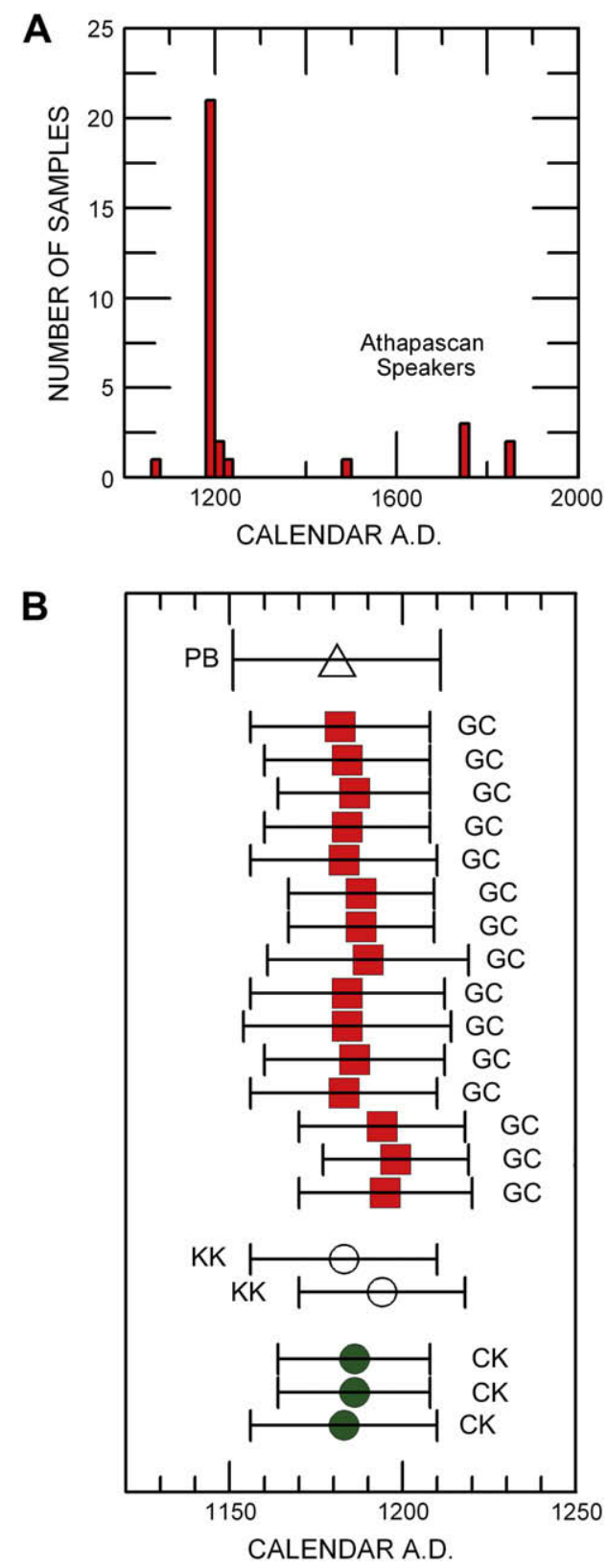

Fig. 2. (A) Calendar-age histogram of archaeological cobs discussed in this paper. (B) Twenty-one cobs from Pueblo Bonito (PB), Gallo Cliff Dwelling (GC), Kin Klizhin (KK), and Chetro Ketl (CK) that have essentially the same age. 
Table 2

Site information, ${ }^{87} \mathrm{Sr} /{ }^{86} \mathrm{Sr}$, and $\mathrm{K} / \mathrm{Rb}$ ratios for synthetic soil-waters from the Southern Colorado Plateau (chemical data are grouped by location)

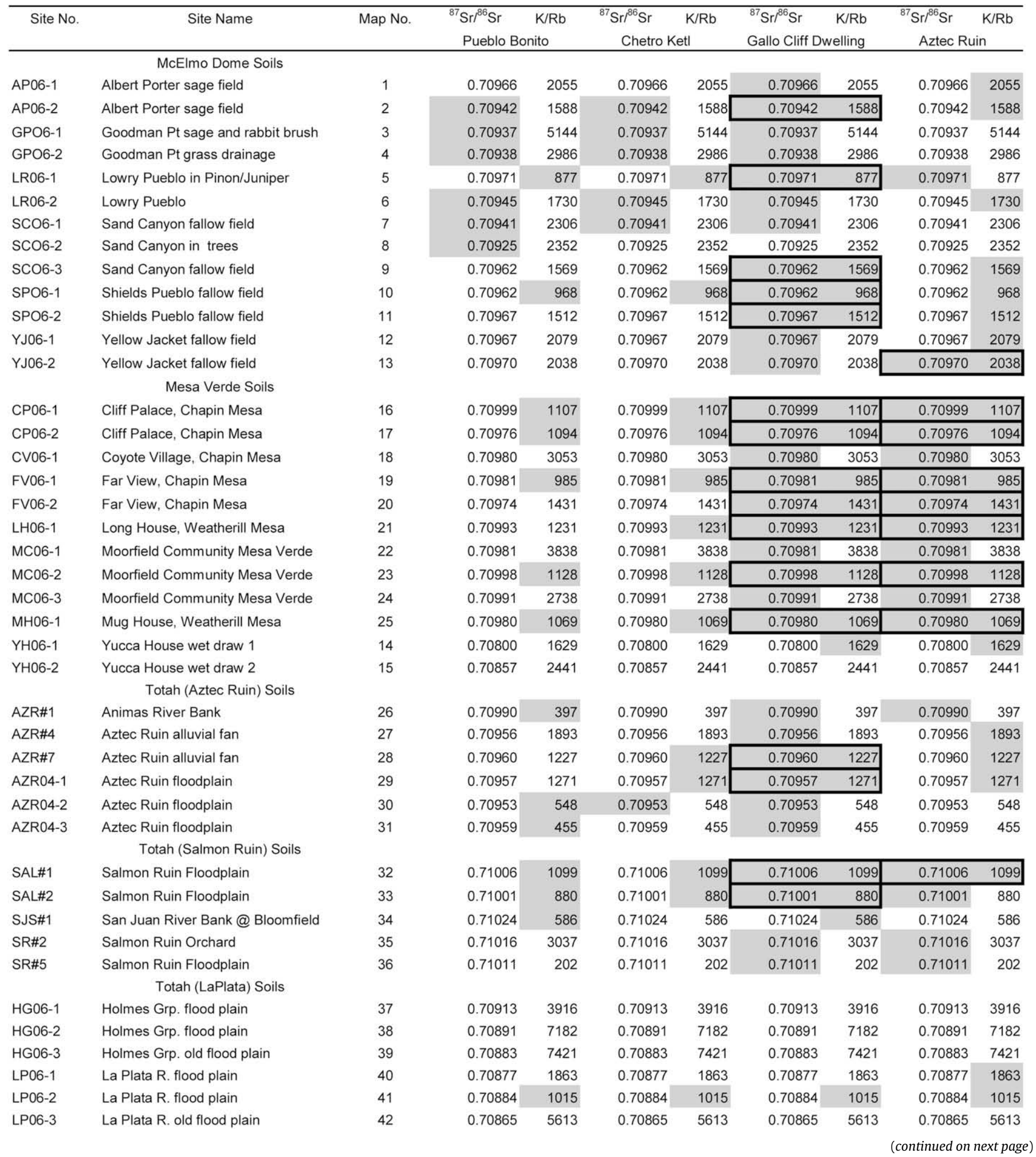


Table 2 (continued)

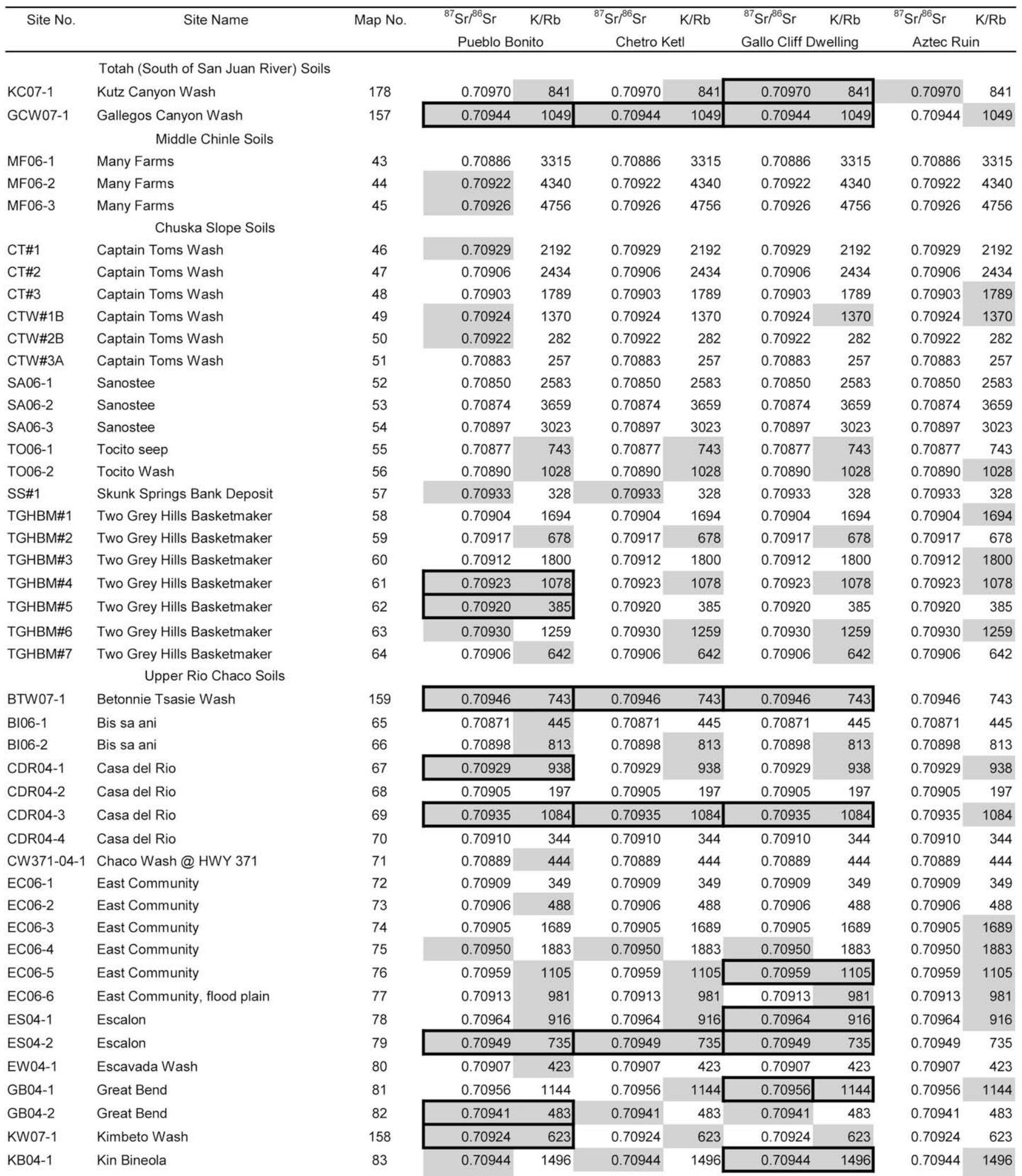


Table 2 (continued)

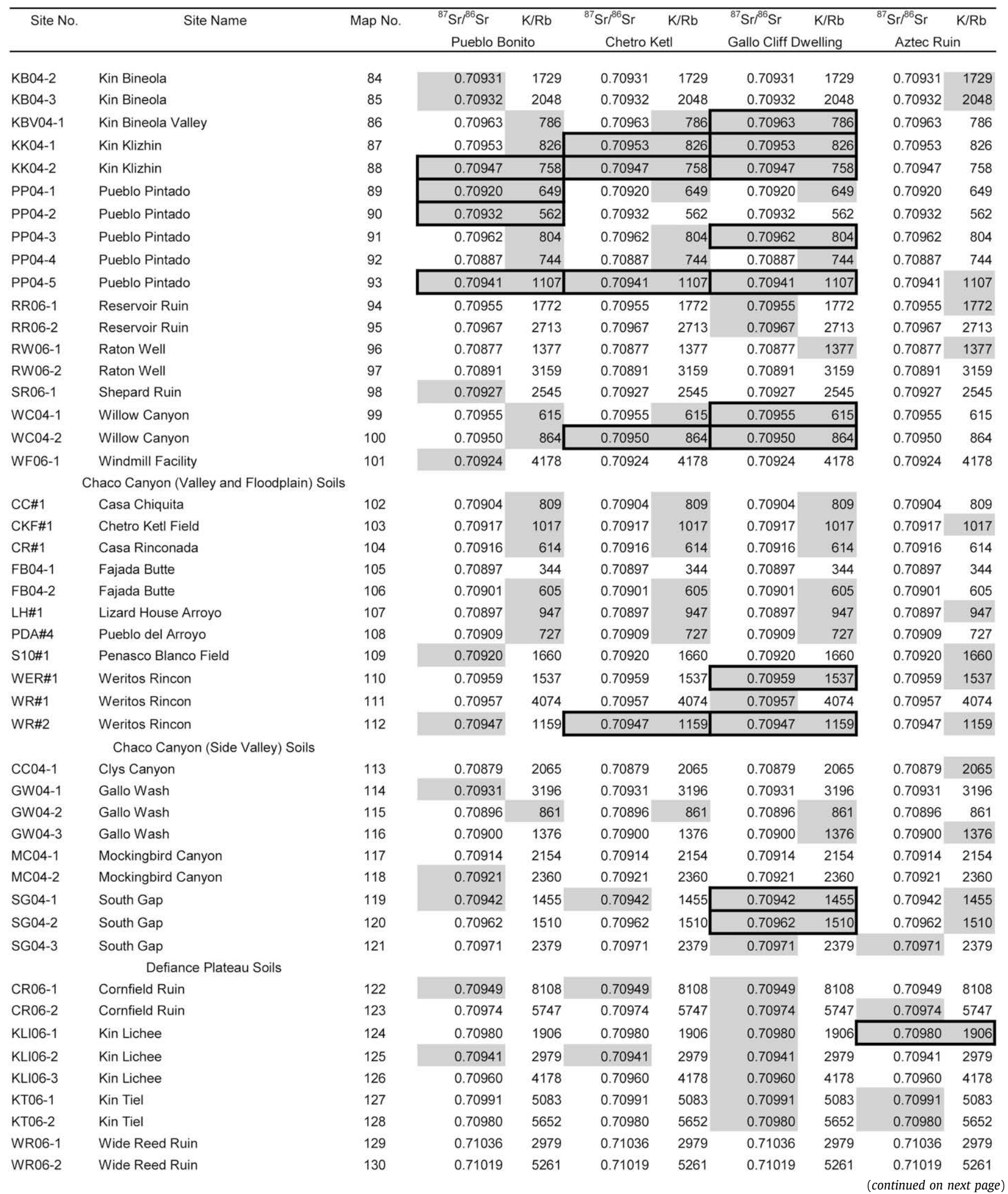


Table 2 (continued)

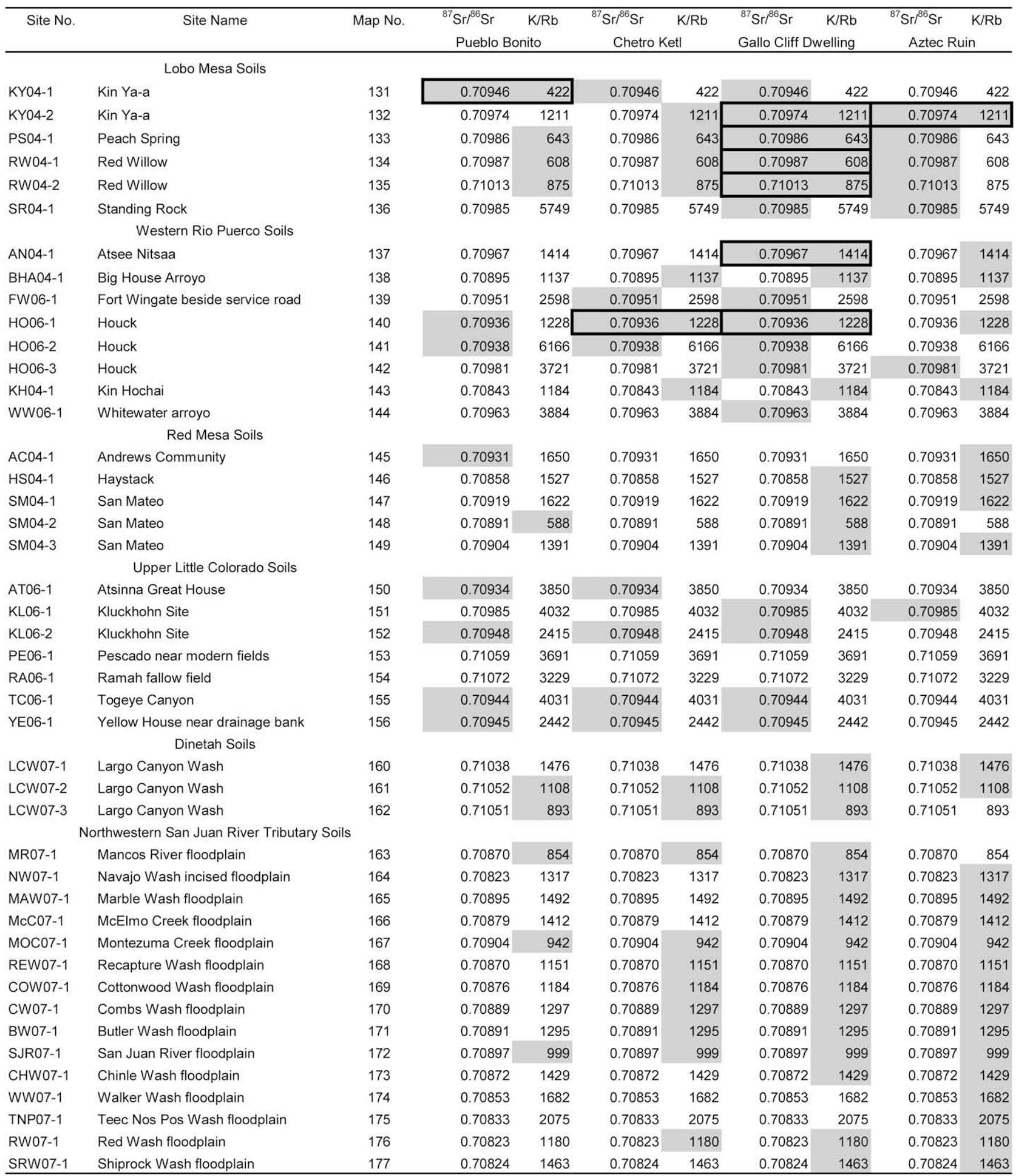

Grey-shaded samples indicate a match between a soil-water's ${ }^{87} \mathrm{Sr} /{ }^{86} \mathrm{Sr}$ value or its $\mathrm{K} / \mathrm{Rb}$ value and the range of values in a cob data set. Rectangle indicates a soil-water whose ${ }^{87} \mathrm{Sr} /{ }^{86} \mathrm{Sr}$ and $\mathrm{K} / \mathrm{Rb}$ ratios both match values in a cob data set.

$\mathrm{K} / \mathrm{Rb}$ ratios are accurate to only three significant figures.

(Fig. 2B) with the mean and standard deviation of the 1-sigma midpoint calendar ages being A.D. $1187 \pm 5$.

Based on their accelerator mass spectrometric (AMS) ${ }^{14} \mathrm{C}$ ages (Table 1 ), the $36{ }^{14} \mathrm{C}$-dated Chaco cobs can be split into three groups: a pre-middle-12th-century (pre-A.D. 1130) drought group (when Chaco was in its heyday), a post-middle-12th-century (postA.D. 1180) drought group (by this time the Chacoan system had collapsed and the canyon contained only a small residual 
population), and a post late-13th-century (post-A.D. 1300) drought group (a time when Athapascan speakers occupied the canyon that had been previously abandoned by the Anasazi).

In the following, we discuss the ${ }^{87} \mathrm{Sr} /{ }^{86} \mathrm{Sr}$ and $\mathrm{K} / \mathrm{Rb}$ ratios of the archaeological cobs (Table 1 ) in terms of their provenience (where they were found) and in terms of their calibrated ages (when they were grown and brought to Chaco Canyon/Aztec Ruin).

\subsection{Trace-metal ratios of the archaeological cobs}

When we began to use trace-metal distribution coefficients to calculate the trace-metal ratios for the soil-waters in which the archaeological cobs grew, we realized there was a problem. For example, when we used measured $\mathrm{Ba} / \mathrm{Mn}$ ratios in cobs to calculate soil-water $\mathrm{Ba} / \mathrm{Mn}$ ratios by substitution into Eq. (1.1), we found that the $\mathrm{Ba} / \mathrm{Mn}$ values of cob-derived soil-waters (Ave $[\mathrm{Ba} / \mathrm{Mn}]_{\mathrm{COB}}$ DERIVED $=7.0 \pm 3.6$ ) were an order of magnitude higher than the $\mathrm{Ba} /$ Mn values of synthetic soil-waters produced by leaching sediment (Ave $[\mathrm{Ba} / \mathrm{Mn}]_{\text {MEASURED }}=0.53 \pm 0.47$ ) (Supplementary Tables $2-4$ ).

To determine if the original cobs were contaminated with soil from the sites in which they were found, we plotted several measured trace-metal concentrations versus aluminum (Al) concentrations (Fig. 3). Aluminum is a principal component of aluminosilicate minerals (e.g., feldspars), but it is not a principal chemical component of plant material; e.g., $\mathrm{Al}$ in the five modern Southwestern Native American landraces analyzed in Benson et al. (2008) averaged only $4.9 \pm 4.4 \mu \mathrm{g} / \mathrm{g}$ and $\mathrm{Al}$ in four modern cobs ranged from 3 to $28 \mu \mathrm{g} / \mathrm{g}$ (unpublished data of H. E. Taylor, USGS). In the Pueblo Bonito, Aztec Ruin, and 30 new cob data sets, Al values ranged, respectively, from 50 to $1000 \mu \mathrm{g} / \mathrm{g}$, from 58 to $1100 \mu \mathrm{g} / \mathrm{g}$, and from 29 to $3140 \mu \mathrm{g} / \mathrm{g}$ (Supplementary Tables 3 and 4), which suggests that some and perhaps most of the cobs had been contaminated with soil or windblown mineral dust which contained aluminosilicate minerals.

The metal-Al plots (Fig. 3) indicate that most of the cobs contain soil or dust particles that dissolved along with the ashed cobs residues when treated with a combination of strong acids (in particular HF) that were added prior to analysis (see Methods section in supplementary online material). Cerium (Ce) (a rareearth element [REE] common in feldspars and igneous accessory minerals such as sphene, zircon, and allanite) indicates a nearly $1: 1$ correlation with $\mathrm{Al}$ (Fig. 3). The high-degree of correlation with $\mathrm{Al}$ is also true for a number of other metals, including $\mathrm{Li}, \mathrm{Fe}, \mathrm{V}, \mathrm{Zr}$, and all the REEs (data not shown), suggesting the dissolution of differing

Table 3

Line-of-sight distances from Aztec Ruin and Chaco Canyon to potential maize source regions

\begin{tabular}{llr}
\hline Source area & Chaco Canyon & Aztec Ruin \\
\cline { 2 - 3 } & Distance $(\mathrm{km})$ & \\
\hline McElmo Dome & 160 & 95 \\
Mesa Verde & 120 & 0 \\
Totah & 75 & \\
Dinetah & 65 & \\
Chuska Slope & 80 & 110 \\
Upper Rio Chaco (W) & 50 & \\
Upper Rio Chaco (E) & 35 & 180 \\
Lobo Mesa & 45 & \\
Western Rio Puerco & 105 & \\
Defiance Plateau & 140 & \\
\hline
\end{tabular}

Distances are measured from the center of each potential source region.

Upper Rio Chaco (W) refers to the far western end of the Upper Rio Chaco source region.

Upper Rio Chaco (E) refers to the far eastern end of the Upper Rio Chaco source region. amounts of an aluminosilicate mineral with a nearly constant composition.

Also shown in Fig. 3 are plots of each of the trace-metals (Ca, Ba, $\mathrm{Mn}, \mathrm{Sr}, \mathrm{K}, \mathrm{Rb}$ ) associated with the four trace-metal $K_{\mathrm{D}}$. Barium and $\mathrm{Mn}$ are highly correlated with $\mathrm{Al}$ (Fig. 3C, D) and $\mathrm{Sr}$ and $\mathrm{Ca}$ also exhibit significant correlations with $\mathrm{Al}$ when it exceeds $800 \mu \mathrm{g} / \mathrm{g}$ (Fig. 3A, B, F, G). Only K and Rb, appear uncorrelated with Al when its concentration is less than $250 \mu \mathrm{g} / \mathrm{g}\left(R^{2}<0.02\right)$ (Fig. $\left.3 \mathrm{H}, \mathrm{I}, \mathrm{J}\right)$. Given the high correlations of some of the trace-metals with Al, we decided to use only cob-derived soil-water $\mathrm{K} / \mathrm{Rb}$ ratios for those 28 cobs whose Al values were $<250 \mu \mathrm{g} / \mathrm{g}$ (Supplementary Tables 3 and 4). Note that four cobs having anomalously high $\mathrm{Sr}$ values (Fig. 3A) (the Una Vida and Kin Kletso cobs as well as Aztec cobs AZRU 9651 and AZRU 11091), indicating contamination with soil-derived Sr, were excluded from further consideration in this paper.

Histograms illustrating the $\mathrm{K} / \mathrm{Rb}$ ratios of archaeological cobs (Supplementary Table 3) from four Chaco Canyon locations and from Aztec West Ruin are displayed in Supplementary Figure 2A-E. Pueblo Bonito, Chetro Ketl, Gallo Cliff Dwelling, and Aztec West Ruin cobs have calculated soil-water $\mathrm{K} / \mathrm{Rb}$ ranges of, respectively, 511-873, 845-1000, 832-1257, and 705-1599 (except for one Aztec West Ruin cob which has a soil-water K/Rb ratio of 216) (Supplementary Tables 3 and 4; Supplementary Figure 2). Given that the percent relative standard deviation (\%RSD) of the $\mathrm{K} / \mathrm{Rb}$ distribution coefficient is $\sim 30 \%$, we increased the calculated soil-water $\mathrm{K} / \mathrm{Rb}$ ranges by $\pm 30 \%$ to account for this variance. Thus, Pueblo Bonito, Chetro Ketl, Gallo Cliff Dwelling, and Aztec West Ruin cobs have adjusted soil-water $\mathrm{K} / \mathrm{Rb}$ ranges of, respectively, 358-1135, 5921300, 582-1634, and 916-2079.

The calculated soil-water K/Rb ratios of five pre-A.D. 1130 and 13 post-A.D. 1180 cobs range, respectively, from 511 to 613 and from 765 to 1257 (Supplementary Tables 3 and 4). Their \%RSD-adjusted ratios $^{1}$ range, respectively, from 358 to 797 and from 536 to 1634 . The two post-A.D. 1300 Athapascan-age samples have K/Rb values of 683 and 1984, which correspond to \%RSD-adjusted ranges of 478-888 and 1389-2579.

Fig. 4 is a contour plot of synthetic soil-water $\mathrm{K} / \mathrm{Rb}$ ratios for the San Juan Basin and adjacent areas. Contour intervals occupied by pre-A.D. 1130 and post-A.D. 1180 cob-based soil-waters are shown in shades of grey. For plotting purposes, the pre-A.D. 1130 and postA.D. $1180 \mathrm{~K} / \mathrm{Rb}$ ranges have been set to $360-800$ and $540-1600$. Much of southwestern Colorado, northeastern Arizona, the northcentral San Juan Basin, and a wedge-shaped area south of the Upper Rio Chaco has soil-water ratios higher than that recorded by the cobs and, as such, are ruled out as cob source areas.

\section{3. ${ }^{87} \mathrm{Sr} /{ }^{86} \mathrm{Sr}$ ratios of archaeological cobs}

Histograms illustrating the ${ }^{87} \mathrm{Sr} /{ }^{86} \mathrm{Sr}$ ratios of archaeological cobs (Table 1) from four Chaco Canyon locations and from Aztec West Ruin are displayed in Fig. $5 \mathrm{~A}-\mathrm{E}$. The ${ }^{87} \mathrm{Sr} /{ }^{86} \mathrm{Sr}$ ratios of cobs from Pueblo Bonito, Chetro Ketl, Gallo Cliff Dwelling, and Aztec West Ruin range, respectively, from 0.70922 to 0.70948 (with one outlier at 0.70989 ), from 0.70935 to 0.70955 , from 0.70941 to 0.71158 , and from 0.70969 to 0.71017 (with one outlier at 0.71031 ) (Fig. 5A-D).

The three Chaco cob age groups (pre-A.D. 1130, post-A.D. 1180, and post-A.D. 1300) (Table 1 ) have ${ }^{87} \mathrm{Sr} /{ }^{86} \mathrm{Sr}$ ranges of $0.70922-$ 0.70989 (five of five pre-A.D. 1130 samples), 0.70935-0.71027 (18 of 21 post-A.D. 1180 samples), $0.71088-0.71158$ (three of 21 post-A.D.

\footnotetext{
${ }^{1}$ In calculating the \%RSD adjusted ratios the value of the standard deviation of the minimum value in the range of values was subtracted from the minimum value and the standard deviation of the maximum value in the range of values was added to the maximum value.
} 
Table 4

Site information, ${ }^{87} \mathrm{Sr} /{ }^{86} \mathrm{Sr}$, and $\mathrm{K} / \mathrm{Rb}$ ratios for synthetic soil-waters from the Southern Colorado Plateau (chemical data are grouped by time)

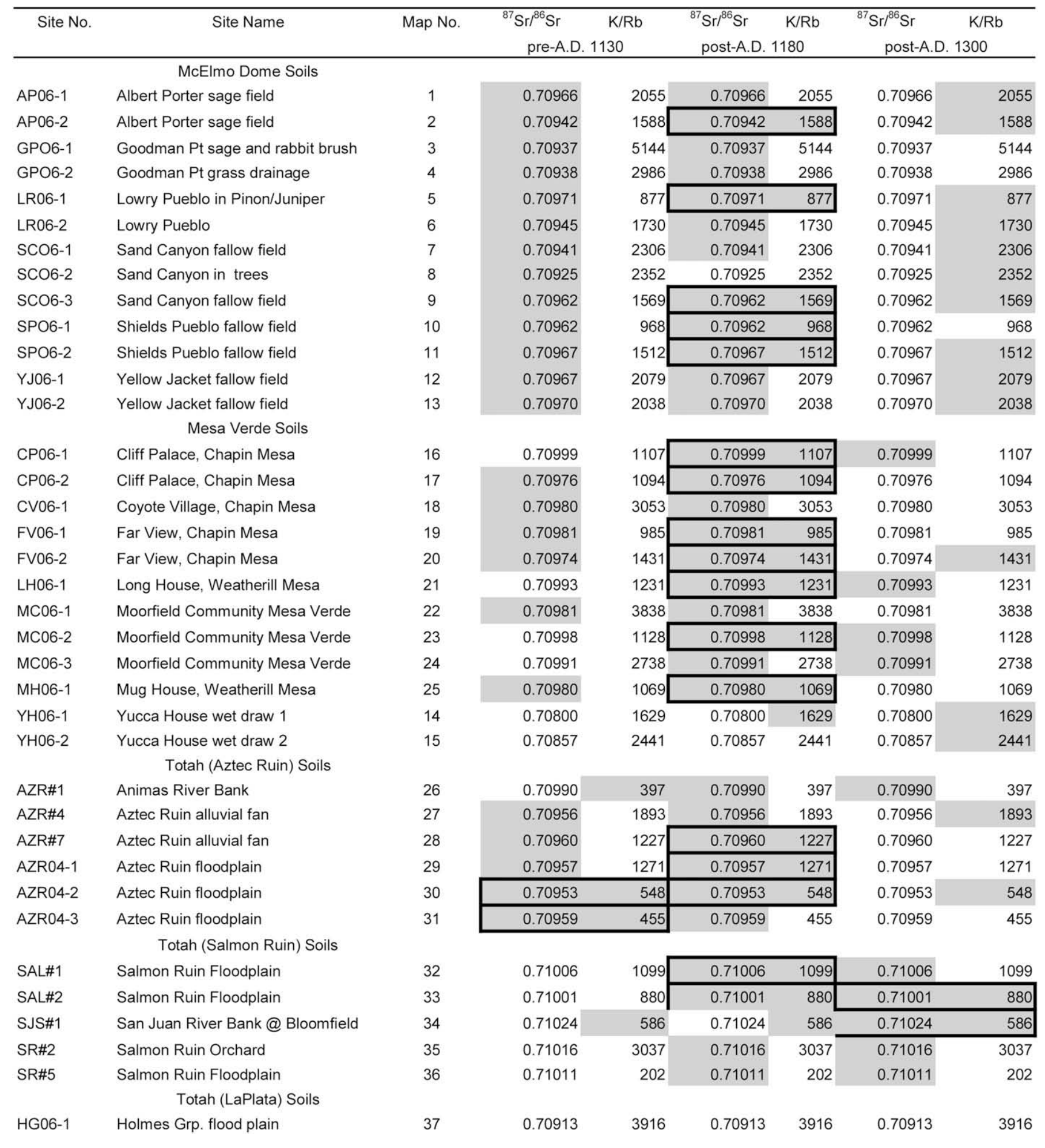


Table 4 (continued)

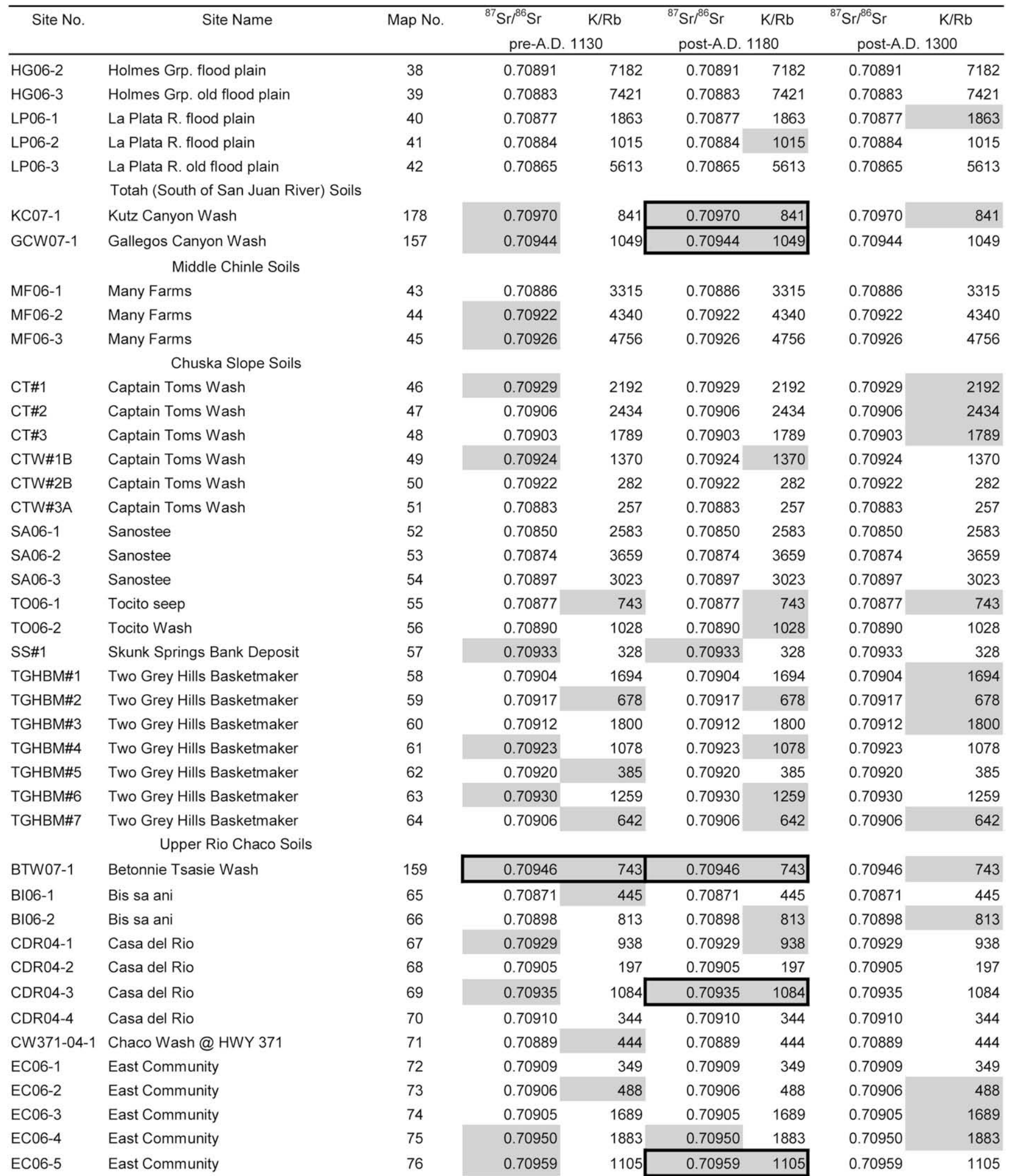


Table 4 (continued)

\begin{tabular}{|c|c|c|c|c|c|c|c|c|}
\hline \multirow[t]{2}{*}{ Site No. } & \multirow[t]{2}{*}{ Site Name } & \multirow[t]{2}{*}{ Map No. } & & $\mathrm{K} / \mathrm{Rb}$ & & $\mathrm{K} / \mathrm{Rb}$ & & $\mathrm{K} / \mathrm{Rb}$ \\
\hline & & & \multicolumn{2}{|c|}{ pre-A.D. 1130} & \multicolumn{2}{|c|}{ post-A.D. 1180} & \multicolumn{2}{|c|}{ post-A.D. 1300} \\
\hline EC06-6 & East Community, flood plain & 77 & 0.70913 & 981 & 0.70913 & 981 & 0.70913 & 981 \\
\hline ESO4-2 & Escalon & 79 & 0.70949 & 735 & 0.70949 & 735 & 0.70949 & 735 \\
\hline EW04-1 & Escavada Wash & 80 & 0.70907 & 423 & 0.70907 & 423 & 0.70907 & 423 \\
\hline KW07-1 & Kimbeto Wash & 158 & 0.70924 & 623 & 0.70924 & 623 & 0.70924 & 623 \\
\hline KB04-1 & Kin Bineola & 83 & 0.70944 & 1496 & 0.70944 & 1496 & 0.70944 & 1496 \\
\hline KB04-2 & Kin Bineola & 84 & 0.70931 & 1729 & 0.70931 & 1729 & 0.70931 & 1729 \\
\hline KB04-3 & Kin Bineola & 85 & 0.70932 & 2048 & 0.70932 & 2048 & 0.70932 & 2048 \\
\hline PP04-2 & Pueblo Pintado & 90 & 0.70932 & 562 & 0.70932 & 562 & 0.70932 & 562 \\
\hline PP04-3 & Pueblo Pintado & 91 & 0.70962 & 804 & 0.70962 & 804 & 0.70962 & 804 \\
\hline PP04-4 & Pueblo Pintado & 92 & 0.70887 & 744 & 0.70887 & 744 & 0.70887 & 744 \\
\hline PP04-5 & Pueblo Pintado & 93 & 0.70941 & 1107[ & 0.70941 & 1107 & 0.70941 & 1107 \\
\hline RR06-1 & Reservoir Ruin & 94 & 0.70955 & 1772 & 0.70955 & 1772 & 0.70955 & 1772 \\
\hline RR06-2 & Reservoir Ruin & 95 & 0.70967 & 2713 & 0.70967 & 2713 & 0.70967 & 2713 \\
\hline RW06-1 & Raton Well & 96 & 0.70877 & 1377 & 0.70877 & 1377 & 0.70877 & 1377 \\
\hline RW06-2 & Raton Well & 97 & 0.70891 & 3159 & 0.70891 & 3159 & 0.70891 & 3159 \\
\hline SR06-1 & Shepard Ruin & 98 & 0.70927 & 2545 & 0.70927 & 2545 & 0.70927 & 2545 \\
\hline FB04-1 & Fajada Butte & 105 & 0.70897 & 344 & 0.70897 & 344 & 0.70897 & 344 \\
\hline FB04-2 & Fajada Butte & 106 & 0.70901 & 605 & 0.70901 & 605 & 0.70901 & 605 \\
\hline LH\#1 & Lizard House Arroyo & 107 & 0.70897 & 947 & 0.70897 & 947 & 0.70897 & 947 \\
\hline PDA\#4 & Pueblo del Arroyo & 108 & 0.70909 & 727 & 0.70909 & 727 & 0.70909 & 727 \\
\hline S10\#1 & Penasco Blanco Field & 109 & 0.70920 & 1660 & 0.70920 & 1660 & 0.70920 & 1660 \\
\hline WER\#1 & Weritos Rincon & 110 & 0.70959 & 1537 & 0.70959 & 1537 & 0.70959 & 1537 \\
\hline WR\#1 & Weritos Rincon & 111 & 0.70957 & 4074 & 0.70957 & 4074 & 0.70957 & 4074 \\
\hline \multirow[t]{2}{*}{ WR\#2 } & Weritos Rincon & 112 & 0.70947 & 1159[ & 0.70947 & 1159 & 0.70947 & 1159 \\
\hline & Chaco Canyon (Side Valle & & & & & & & \\
\hline $\mathrm{CC} 04-1$ & Clys Canyon & 113 & 0.70879 & 2065 & 0.70879 & 2065 & 0.70879 & 2065 \\
\hline GW04-1 & Gallo Wash & 114 & 0.70931 & 3196 & 0.70931 & 3196 & 0.70931 & 3196 \\
\hline GW04-2 & Gallo Wash & 115 & 0.70896 & 861 & 0.70896 & 861 & 0.70896 & 861 \\
\hline GW04-3 & Gallo Wash & 116 & 0.70900 & 1376 & 0.70900 & 1376 & 0.70900 & 1376 \\
\hline MC04-1 & Mockingbird Canyon & 117 & 0.70914 & 2154 & 0.70914 & 2154 & 0.70914 & 2154 \\
\hline MC04-2 & Mockingbird Canyon & 118 & 0.70921 & 2360 & 0.70921 & 2360 & 0.70921 & 2360 \\
\hline
\end{tabular}


Table 4 (continued)

\begin{tabular}{|c|c|c|c|c|c|c|c|c|}
\hline \multirow[t]{2}{*}{ Site No. } & \multirow[t]{2}{*}{ Site Name } & \multirow[t]{2}{*}{ Map No. } & ${ }^{87} \mathrm{Sr} /{ }^{86} \mathrm{Sr}$ & $\mathrm{K} / \mathrm{Rb}$ & ${ }^{87} \mathrm{Sr} /{ }^{86} \mathrm{Sr}$ & $\mathrm{K} / \mathrm{Rb}$ & ${ }^{87} \mathrm{Sr} /{ }^{86} \mathrm{Sr}$ & $\mathrm{K} / \mathrm{Rb}$ \\
\hline & & & \multicolumn{2}{|c|}{ pre-A.D. 1130} & \multicolumn{2}{|c|}{ post-A.D. 1180} & \multicolumn{2}{|c|}{ post-A.D. 1300} \\
\hline SG04-1 & South Gap & 119 & 0.70942 & 1455 & 0.70942 & 1455 & 0.70942 & 1455 \\
\hline SG04-3 & South Gap & 121 & 0.70971 & 2379 & 0.70971 & 2379 & 0.70971 & 2379 \\
\hline \multicolumn{9}{|c|}{ Defiance Plateau Soils } \\
\hline KLI06-1 & Kin Lichee & 124 & 0.70980 & 1906 & 0.70980 & 1906 & 0.70980 & 1906 \\
\hline KLI06-2 & Kin Lichee & 125 & 0.70941 & 2979 & 0.70941 & 2979 & 0.70941 & 2979 \\
\hline KLI06-3 & Kin Lichee & 126 & 0.70960 & 4178 & 0.70960 & 4178 & 0.70960 & 4178 \\
\hline KT06-1 & Kin Tiel & 127 & 0.70991 & 5083 & 0.70991 & 5083 & 0.70991 & 5083 \\
\hline KT06-2 & Kin Tiel & 128 & 0.70980 & 5652 & 0.70980 & 5652 & 0.70980 & 5652 \\
\hline KY04-1 & Kin Ya-a & 131 & 0.70946 & 422 & 0.70946 & 422 & 0.70946 & 422 \\
\hline KY04-2 & Kin Ya-a & 132 & 0.70974 & 1211 & 0.70974 & 1211 & 0.70974 & 1211 \\
\hline PS04-1 & Peach Spring & 133 & 0.70986 & 643 & 0.70986 & 643 & 0.70986 & 643 \\
\hline RW04-1 & Red Willow & 134 & 0.70987 & 608 & 0.70987 & 608 & 0.70987 & 608 \\
\hline RW04-2 & Red Willow & 135 & 0.71013 & 875 & 0.71013 & 875 & 0.71013 & 875 \\
\hline SR04-1 & Standing Rock & 136 & 0.70985 & 5749 & 0.70985 & 5749 & 0.70985 & 5749 \\
\hline \multicolumn{9}{|c|}{ Western Rio Puerco Soils } \\
\hline AN04-1 & Atsee Nitsaa & 137 & 0.70967 & 1414 & 0.70967 & 1414 & 0.70967 & 1414 \\
\hline BHA04-1 & Big House Arroyo & 138 & 0.70895 & 1137 & 0.70895 & 1137 & 0.70895 & 1137 \\
\hline FW06-1 & Fort Wingate beside service road & 139 & 0.70951 & 2598 & 0.70951 & 2598 & 0.70951 & 2598 \\
\hline AC04-1 & Andrews Community & 145 & 0.70931 & 1650 & 0.70931 & 1650 & 0.70931 & 1650 \\
\hline HS04-1 & Haystack & 146 & 0.70858 & 1527 & 0.70858 & 1527 & 0.70858 & 1527 \\
\hline SM04-1 & San Mateo & 147 & 0.70919 & 1622 & 0.70919 & 1622 & 0.70919 & 1622 \\
\hline SM04-2 & San Mateo & 148 & 0.70891 & 588 & 0.70891 & 588 & 0.70891 & 588 \\
\hline SM04-3 & San Mateo & 149 & 0.70904 & 1391 & 0.70904 & 1391 & 0.70904 & 1391 \\
\hline \multicolumn{9}{|c|}{ Upper Little Colorado Soils } \\
\hline AT06-1 & Atsinna Great House & 150 & 0.70934 & 3850 & 0.70934 & 3850 & 0.70934 & 3850 \\
\hline KL06-1 & Kluckhohn Site & 151 & 0.70985 & 4032 & 0.70985 & 4032 & 0.70985 & 4032 \\
\hline KL06-2 & Kluckhohn Site & 152 & 0.70948 & 2415 & 0.70948 & 2415 & 0.70948 & 2415 \\
\hline PE06-1 & Pescado near modern fields & 153 & 0.71059 & 3691 & 0.71059 & 3691 & 0.71059 & 3691 \\
\hline RA06-1 & Ramah fallow field & 154 & 0.71072 & 3229 & 0.71072 & 3229 & 0.71072 & 3229 \\
\hline TC06-1 & Togeye Canyon & 155 & 0.70944 & 4031 & 0.70944 & 4031 & 0.70944 & 4031 \\
\hline YE06-1 & Yellow House near drainage bank & 156 & 0.70945 & 2442 & 0.70945 & 2442 & 0.70945 & 2442 \\
\hline \multicolumn{9}{|c|}{ Dinetah Soils } \\
\hline LCW07-1 & Largo Canyon Wash & 160 & 0.71038 & 1476 & 0.71038 & 1476 & 0.71038 & 1476 \\
\hline
\end{tabular}


Table 4 (continued)

\begin{tabular}{|c|c|c|c|c|c|c|c|c|}
\hline \multirow[t]{2}{*}{ Site No. } & \multirow[t]{2}{*}{ Site Name } & \multirow[t]{2}{*}{ Map No. } & $\left.{ }^{87} \mathrm{Sr}\right|^{86} \mathrm{Sr}$ & $\mathrm{K} / \mathrm{Rb}$ & ${ }^{87} \mathrm{Sr} /{ }^{86} \mathrm{Sr}$ & $\mathrm{K} / \mathrm{Rb}$ & ${ }^{87} \mathrm{Sr} /^{86} \mathrm{Sr}$ & $\mathrm{K} / \mathrm{Rb}$ \\
\hline & & & \multicolumn{2}{|c|}{ pre-A.D. 1130} & \multicolumn{2}{|c|}{ post-A.D. 1180} & \multicolumn{2}{|c|}{ post-A.D. 1300} \\
\hline LCW07-2 & Largo Canyon Wash & 161 & 0.71052 & 1108 & 0.71052 & 1108 & 0.71052 & 1108 \\
\hline \multicolumn{9}{|c|}{ Northwestern San Juan River Tributary Soils } \\
\hline MR07-1 & Mancos River floodplain & 163 & 0.70870 & 854 & 0.70870 & 854 & 0.70870 & 854 \\
\hline $\mathrm{McC} 07-1$ & McElmo Creek floodplain & 166 & 0.70879 & 1412 & 0.70879 & 1412 & 0.70879 & 1412 \\
\hline MOC07-1 & Montezuma Creek floodplain & 167 & 0.70904 & 942 & 0.70904 & 942 & 0.70904 & 942 \\
\hline REW07-1 & Recapture Wash floodplain & 168 & 0.70870 & 1151 & 0.70870 & 1151 & 0.70870 & 1151 \\
\hline cow07-1 & Cottonwood Wash floodplain & 169 & 0.70876 & 1184 & 0.70876 & 1184 & 0.70876 & 1184 \\
\hline CW07-1 & Combs Wash floodplain & 170 & 0.70889 & 1297 & 0.70889 & 1297 & 0.70889 & 1297 \\
\hline WW07-1 & Walker Wash floodplain & 174 & 0.70853 & 1682 & 0.70853 & 1682 & 0.70853 & 1682 \\
\hline TNP07-1 & Teec Nos Pos Wash floodplain & 175 & 0.70833 & 2075 & 0.70833 & 2075 & 0.70833 & 2075 \\
\hline RW07-1 & Red Wash floodplain & 176 & 0.70823 & 1180 & 0.70823 & 1180 & 0.70823 & 1180 \\
\hline SRW07-1 & Shiprock Wash floodplain & 177 & 0.70824 & 1463 & 0.70824 & 1463 & 0.70824 & 1463 \\
\hline
\end{tabular}

Grey-shaded samples indicate a match between a soil-water's ${ }^{87} \mathrm{Sr} /{ }^{86} \mathrm{Sr}$ value or its $\mathrm{K} / \mathrm{Rb}$ value and the range of values in a cob data set. Rectangle indicates a soil-water whose ${ }^{87} \mathrm{Sr} /{ }^{86} \mathrm{Sr}$ and $\mathrm{K} / \mathrm{Rb}$ ratios both match values in a cob data set.

Comparison is being made between soil-water and cobs grouped by age.

1180 samples), and $0.70984-0.71130$ (five of six post-A.D. 1300 samples).

However, there is a possibility that some cobs also were contaminated with excess $\mathrm{Sr}$ from soil or windblown dust. A detailed plot of $\mathrm{Sr}$ versus $\mathrm{Al}$ (Supplementary Figure 3) shows that the correlation of these two metals previously displayed in Fig. $3 \mathrm{~F}$ is due mainly to cobs from Gallo Cliff Dwelling. In order to guard against $\mathrm{Sr}$ contamination from aluminosilicate minerals we eliminated from consideration those cobs having Al values $>250 \mu \mathrm{g} / \mathrm{g}$ and $\mathrm{Sr}$ values $>30 \mu \mathrm{g} / \mathrm{g}$. This resulted in the elimination of 20 cobs shown in bold in Table 1 and Supplementary Tables 3 and 4.

The ${ }^{87} \mathrm{Sr} /{ }^{86} \mathrm{Sr}$ ratios of the remaining uncontaminated cobs from Pueblo Bonito, Chetro Ketl, Gallo Cliff Dwelling, and Aztec West Ruin range, respectively, from 0.70922 to 0.70948 (with one outlier at 0.70989 ), from 0.70935 to 0.70952 , from 0.70937 to 0.71014 (with one outlier at 0.71088 ), and from 0.70970 to 0.71017 (with one outlier at 0.71031 ).

The three Chaco uncontaminated cob age groups (pre-A.D. 1130, post-A.D. 1180, and post-A.D. 1300) (Table 1) have ${ }^{87} \mathrm{Sr} /{ }^{86} \mathrm{Sr}$ ranges of 0.70922-0.70989 (five of five pre-A.D. 1130 samples), 0.709350.71014 (11 of 12 post-A.D. 1180 samples) with one outlier having a value of 0.71088 , and $0.70984-0.71008$ (two of two post-A.D. 1300 samples).

\section{4. ${ }^{87} \mathrm{Sr} /{ }^{86} \mathrm{Sr}$ ratios of synthetic soil-waters}

Fig. 6 is a contour map of synthetic soil-water ${ }^{87} \mathrm{Sr} /{ }^{86} \mathrm{Sr}$ ratios. The different grey-shaded contour intervals correspond to the ${ }^{87} \mathrm{Sr} /{ }^{86} \mathrm{Sr}$ ranges associated with pre-A.D. 1130 and post-A.D. 1180 cobs from Chaco Canyon. The ${ }^{87} \mathrm{Sr} /{ }^{86} \mathrm{Sr}$ contour plot indicates that a rather large area, centered on the four corners and which runs southeastward to the eastern edge of the plot and then south to the bottom of the plot, can be ruled out as a cob source area. Another non-source area (white ellipsoid) occurs near the bottom of the plot along the Arizona-New Mexico border. Map numbers associated with soil sites (small black dots in Fig. 6) are displayed in Supplementary Figure 4A, B and, in addition, are associated with site names and ${ }^{87} \mathrm{Sr} /{ }^{86} \mathrm{Sr}$ values in Table 2 . None of the synthetic soilwaters has a ${ }^{87} \mathrm{Sr} /{ }^{86} \mathrm{Sr}$ ratio $>0.71072$ (Supplementary Table 1) which indicates that one uncontaminated Gallo Cliff Dwelling cob falls outside the ${ }^{87} \mathrm{Sr} /{ }^{86} \mathrm{Sr}$ range encompassed by our synthetic soilwater database.

\subsection{Combining $\mathrm{K} / \mathrm{Rb}$ and ${ }^{87} \mathrm{Sr} /{ }^{86} \mathrm{Sr}$ ratios of the archaeological cobs}

To the extent that we trust the $\mathrm{K} / \mathrm{Rb}$ soil-water ratios derived from the archaeological cob chemistries, we can use these data in conjunction with the ${ }^{87} \mathrm{Sr} /{ }^{86} \mathrm{Sr}$ ratios in the cobs to highlight possible source areas where maize may have been grown. A potential problem with the application of the $\mathrm{K} / \mathrm{Rb}$ distribution coefficient is that it was derived from maize grown under optimal conditions (Adams et al., 2006), whereas prehistoric maize was often grown under conditions of limited moisture and nutrient content, which may have altered the partitioning of trace-metal pairs during metal transport from the soil-water into the cob. Given that the precision of the ${ }^{87} \mathrm{Sr} /{ }^{86} \mathrm{Sr}$ ratios is about two digits in the fifth decimal place, we have used this error range to adjust (broaden) the measured ${ }^{87} \mathrm{Sr} /{ }^{86} \mathrm{Sr}$ values associated with a cob's provenience or age .

In Table 2, synthetic soil-water ${ }^{87} \mathrm{Sr} /{ }^{86} \mathrm{Sr}$ and $\mathrm{K} / \mathrm{Rb}$ ratios that are consistent with either cob-derived soil-water ${ }^{87} \mathrm{Sr} /{ }^{86} \mathrm{Sr}$ or $\mathrm{K} / \mathrm{Rb}$ ranges are highlighted in grey for Pueblo Bonito, Chetro Ketl, Gallo Cliff Dwelling, and Aztec Ruin cob data sets. When both ${ }^{87} \mathrm{Sr} /{ }^{86} \mathrm{Sr}$ and $\mathrm{K} / \mathrm{Rb}$ ratios of a synthetic soil-water fall within the calculated soil-water ranges of a cob set, the ${ }^{87} \mathrm{Sr} /{ }^{86} \mathrm{Sr}$ and $\mathrm{K} / \mathrm{Rb}$ values of the synthetic soil-water have been enclosed with a rectangle. These rectangles indicate potential field sites for the archaeological cobs. The cob map numbers in Table 2 are linked to their locations in Figs. 7 and 8. 

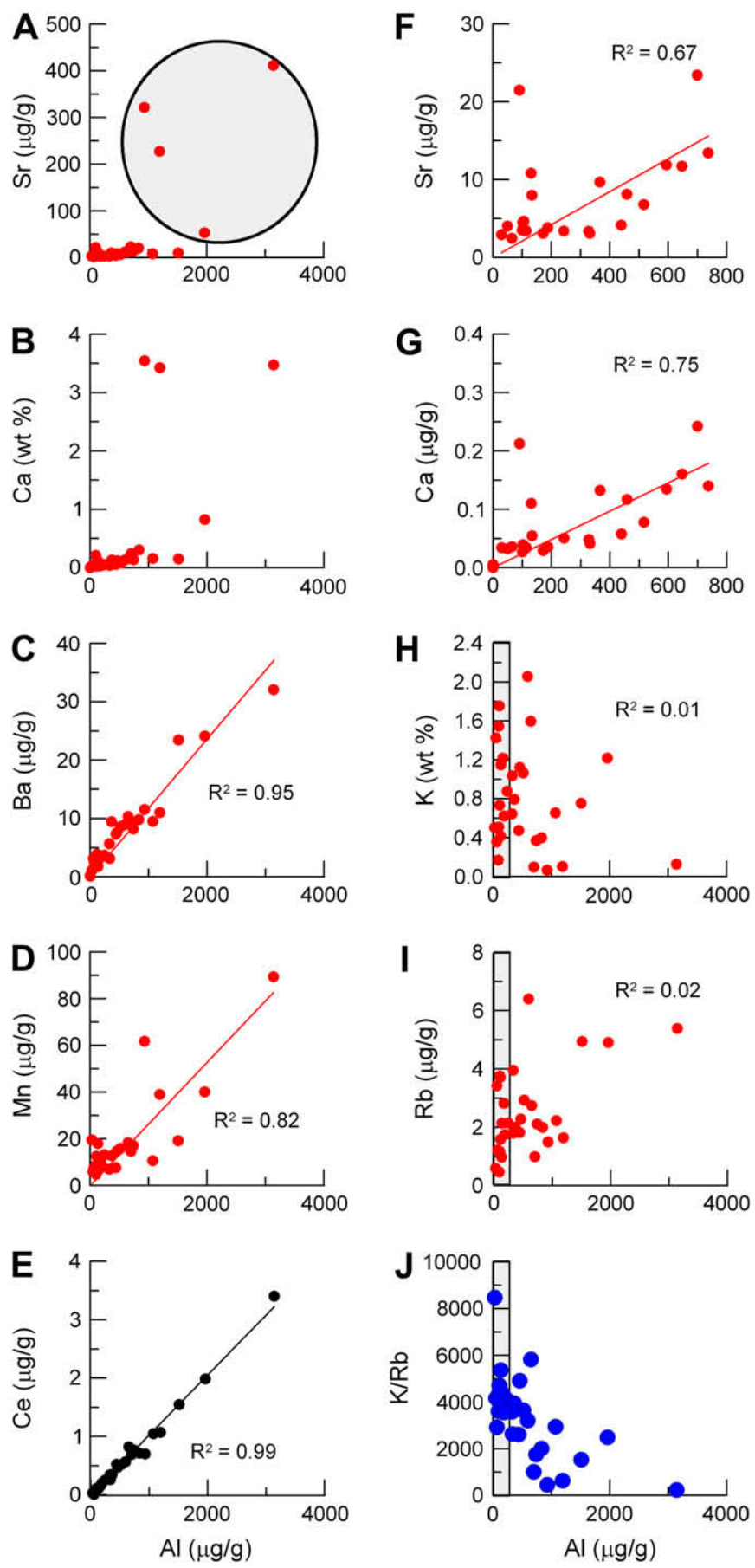

Fig. 3. Trace-metal versus Al correlation plots for archaeological cobs. Shaded circle (A) indicates samples with high $\mathrm{Sr}$ contamination. Thin vertical rectangles indicate regions in which $\mathrm{K}, \mathrm{Rb}$, and $\mathrm{K} / \mathrm{Rb}$ are relatively unaffected by metal contamination.

Potential source areas for Pueblo Bonito cobs include four regions: the Chuska slope region, the Upper Rio Chaco region, the Lobo Mesa region, and the Totah region (Fig. 7A). Potential source areas for Chetro Ketl cobs include three regions: the Totah region, the Upper Rio Chaco region (including one site in Chaco Canyon), and the Western Rio Puerco region (Fig. 7B). Potential source areas for cobs from Gallo Cliff Dwelling include seven regions: the Upper Rio Chaco region (including sites within Chaco Canyon), the Totah region, the Mesa Verde region, the McElmo Dome region, the Lobo Mesa region, and the Western Rio Puerco region (Fig. 7C). Potential source areas for Aztec Ruin cobs include five regions: the Defiance Plateau region, the Lobo Mesa region, the Totah region, the Mesa
Verde region, and the McElmo Dome region (Fig. 7D). The line-ofsight distances from Aztec Ruin and Chaco Canyon to potential cob source regions have been listed in Table 3.

In Table 4, synthetic soil-water ${ }^{87} \mathrm{Sr} /{ }^{86} \mathrm{Sr}$ and $\mathrm{K} / \mathrm{Rb}$ ratios that are consistent with cob-derived soil-water ${ }^{87} \mathrm{Sr} /{ }^{86} \mathrm{Sr}$ and $\mathrm{K} / \mathrm{Rb}$ ranges for the pre-A.D. 1130, post-A.D. 1180, and post-A.D. $1300 \mathrm{cob}$ data sets are highlighted in grey. When both ${ }^{87} \mathrm{Sr} /{ }^{86} \mathrm{Sr}$ and $\mathrm{K} / \mathrm{Rb}$ ratios of a synthetic soil-water fall within the calculated soil-water ranges of cobs, the ${ }^{87} \mathrm{Sr} /{ }^{86} \mathrm{Sr}$ and $\mathrm{K} / \mathrm{Rb}$ values of the synthetic soil-water have been enclosed with a rectangle, which indicates a potential source area for an archaeological cob set.

In terms of their calibrated ages, pre-A.D. 1130 cobs have potential source areas in four regions: the Totah region, the Upper Rio Chaco region and the Lobo Mesa region (Fig. 8A). The post-A.D. 1180 cobs have potential source areas in six regions: the McElmo Dome region, the Mesa Verde region, the Totah region, the Upper Rio Chaco region (including sites in Chaco Canyon), the Lobo Mesa region, and the Western Rio Puerco region (Fig. 8B). Post-A.D. 1300 Athapascan cobs have potential source areas in three regions: the Totah region, the Lobo Mesa region, and the Dinetah region (Fig. 8C).

\section{6. $\mathrm{Cob}^{87} \mathrm{Sr} /{ }^{86} \mathrm{Sr}$ ratios $>0.71072$}

The ${ }^{87} \mathrm{Sr} /{ }^{86} \mathrm{Sr}$ ratios of one uncontaminated cob exceeds a value of 0.71072 (Table 1, CHCU42684-1), the highest synthetic soil-water ${ }^{87} \mathrm{Sr} /{ }^{86} \mathrm{Sr}$ ratio (Table 2); therefore, it is not possible to use the soilwater ${ }^{87} \mathrm{Sr} /{ }^{86} \mathrm{Sr}$ contour plot (Fig. 6) to pinpoint the source(s) of this cob. We can only speculate on areas that might match $\mathrm{cob}^{87} \mathrm{Sr} /{ }^{86} \mathrm{Sr}$ values that exceed $0.71072 .^{2}$ Two San Juan River tributaries, the Piedra River and Los Pinos Creek, have ${ }^{87} \mathrm{Sr} /{ }^{86} \mathrm{Sr}$ values (Supplementary Figure $5 \mathrm{~A}$ ) that are similar to the ${ }^{87} \mathrm{Sr} /{ }^{86} \mathrm{Sr}$ value of the Gallo Cliff Dwelling cob (Table 1). The drainages of these streams flow through and near the Needle Mountains (Fig. 1) in Southwest Colorado; in particular, Los Pinos Creek flows over the Precambrian Eolus granite which is associated with elevated ${ }^{87} \mathrm{Sr} /{ }^{86} \mathrm{Sr}$ values (0.7181-0.7408) (Bickford et al., 1969).

Generally speaking, the ${ }^{87} \mathrm{Sr} /{ }^{86} \mathrm{Sr}$ ratio of the soluble mineral component in a soil will dominate the ${ }^{87} \mathrm{Sr} /{ }^{86} \mathrm{Sr}$ of the soil-water; i.e., the ${ }^{87} \mathrm{Sr} /{ }^{86} \mathrm{Sr}$ ratio of a soil-water will change to reflect the ${ }^{87} \mathrm{Sr} /{ }^{86} \mathrm{Sr}$ ratio of soil $\mathrm{Sr}$ released to the water during dissolution of soluble Sr-bearing minerals. Benson et al. (2006) mixed $100 \mathrm{~mL}$ of runoff from the Chuska slope area with $5 \mathrm{~g}$ of soil from two Chaco Canyon sites and showed that about half of the $\mathrm{Sr}$ in the leachate was derived from the soil. Given that a water:soil ratio of $50: 1$ typified the experiment and that a water:soil ratio of $\sim 1: 1$ is more likely to occur in an actual field setting, the ${ }^{87} \mathrm{Sr} /{ }^{86} \mathrm{Sr}$ value of the soluble mineral component in soil is likely to dominant the ${ }^{87} \mathrm{Sr} /{ }^{86} \mathrm{Sr}$ value of precipitation or irrigation water added to a soil.

There is, however, a situation in which a surface-water's ${ }^{87} \mathrm{Sr} /{ }^{86} \mathrm{Sr}$ value is primarily controlled by the ${ }^{87} \mathrm{Sr} /{ }^{86} \mathrm{Sr}$ value of soilwater. This occurs where shallow ground water has reached equilibrium with the soluble $\mathrm{Sr}$ in soils through which the ground water has flowed before it enters a surface-water system. For example, by the time ground water reaches the distal end of a side-tributary fan and before it discharges to a perennial or ephemeral stream, it may have acquired the ${ }^{87} \mathrm{Sr} /{ }^{86} \mathrm{Sr}$ value of the soluble soil minerals through which it passed. In this case, the ${ }^{87} \mathrm{Sr} /{ }^{86} \mathrm{Sr}$ value of a stream that has receives the majority of its input from such ground water is already in equilibrium with the sediments in its floodplain. Therefore, maize growing in the floodplain will have ${ }^{87} \mathrm{Sr} /{ }^{86} \mathrm{Sr}$

\footnotetext{
2 Bedrock shales and sandstones from Chaco Canyon, of poorly indurated siltstones from north of Aztec Ruin, and of sands and gravels from north of Salmon Ruin have ${ }^{87} \mathrm{Sr} /{ }^{86} \mathrm{Sr}$ values $<0.71072$ (Table $21-3$ in Benson et al., 2006).
} 


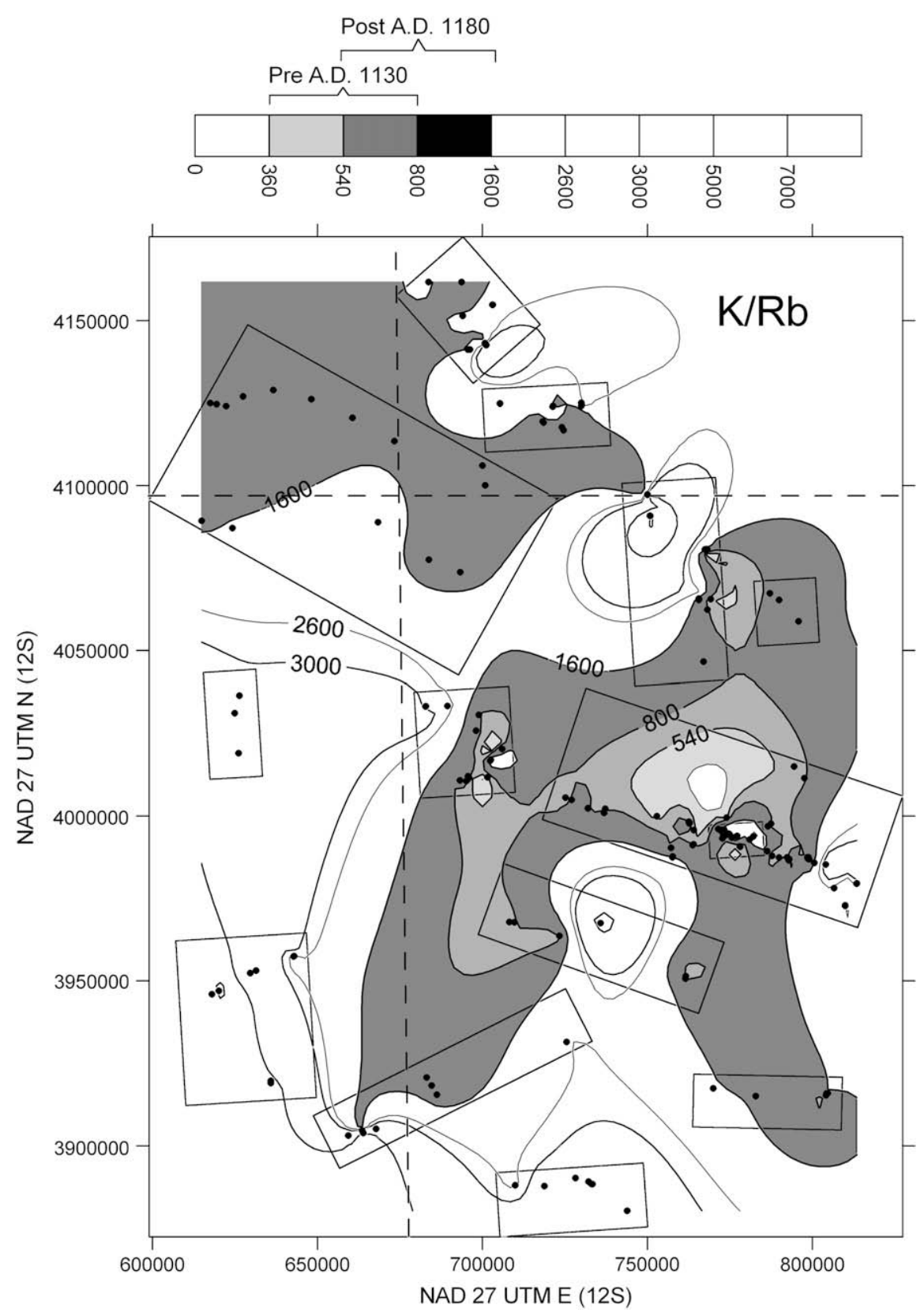

Fig. 4. $\mathrm{K} / \mathrm{Rb}$ contour plot for synthetic soil-waters in the Southern Colorado Plateau region. Black dots indicate sites where soils were sampled. Rectangles bound sampling regions shown in Fig. 1 and listed in Table 2.

values nearly identical to the ${ }^{87} \mathrm{Sr} /{ }^{86} \mathrm{Sr}$ value of $\mathrm{Sr}$ dissolved in the stream.

English et al. (2001) have shown that Tertiary sandstones and quartzites in the Chuska Mountains (85 km west of Chaco) and Precambrian granites, Paleozoic carbonates, and Paleozoic sandstones in the San Pedro Mountains (90 km east of Chaco) have elevated ${ }^{87} \mathrm{Sr} /{ }^{86} \mathrm{Sr}$ ratios (Fig. 1). It is possible that fields were established in sediments at the bases of these mountain ranges or at higher elevations that remained productive during drought periods.

\section{Summary and discussion}

Superimposing Figs. 4 and 6 shows that Anasazi-age cobs from Chaco Canyon have potential source areas that form a "V" with its apex near Pueblo Pintado at the eastern end of the Upper Rio Chaco region (Fig. 8D). The pre-A.D. 1130 Anasazi cobs (five of six which are from Pueblo Bonito) (Table 1) have potential source areas in the upper Rio Chaco and surrounding regions; however, Chaco Canyon itself is not a potential source area (Figs. 7A, 8A). Although we cannot exclude the Totah and Lobo Mesa regions, we suggest that the most probable source(s) for pre-A.D. 1130 Anasazi cobs was the Upper Rio Chaco.

The post-A.D 1180 cobs, which were found in a variety of "Downtown Chaco" sites (Gallo Cliff Dwelling and the Pueblo Bonito, Chetro Ketl, and Kin Klizhin great houses), have potential source areas in the upper Rio Chaco and surrounding regions (excepting the Chuska slope) as well as regions to the northwest (McElmo Dome and Mesa Verde) and to the southwest (western Rio Puerco) (Fig. 8B). Most (15 of 23) of the post-A.D 1180 cobs came from Gallo Cliff Dwelling whose potential cob source regions (Fig. 7C) are nearly the same as the post-A.D 1180 cob source 

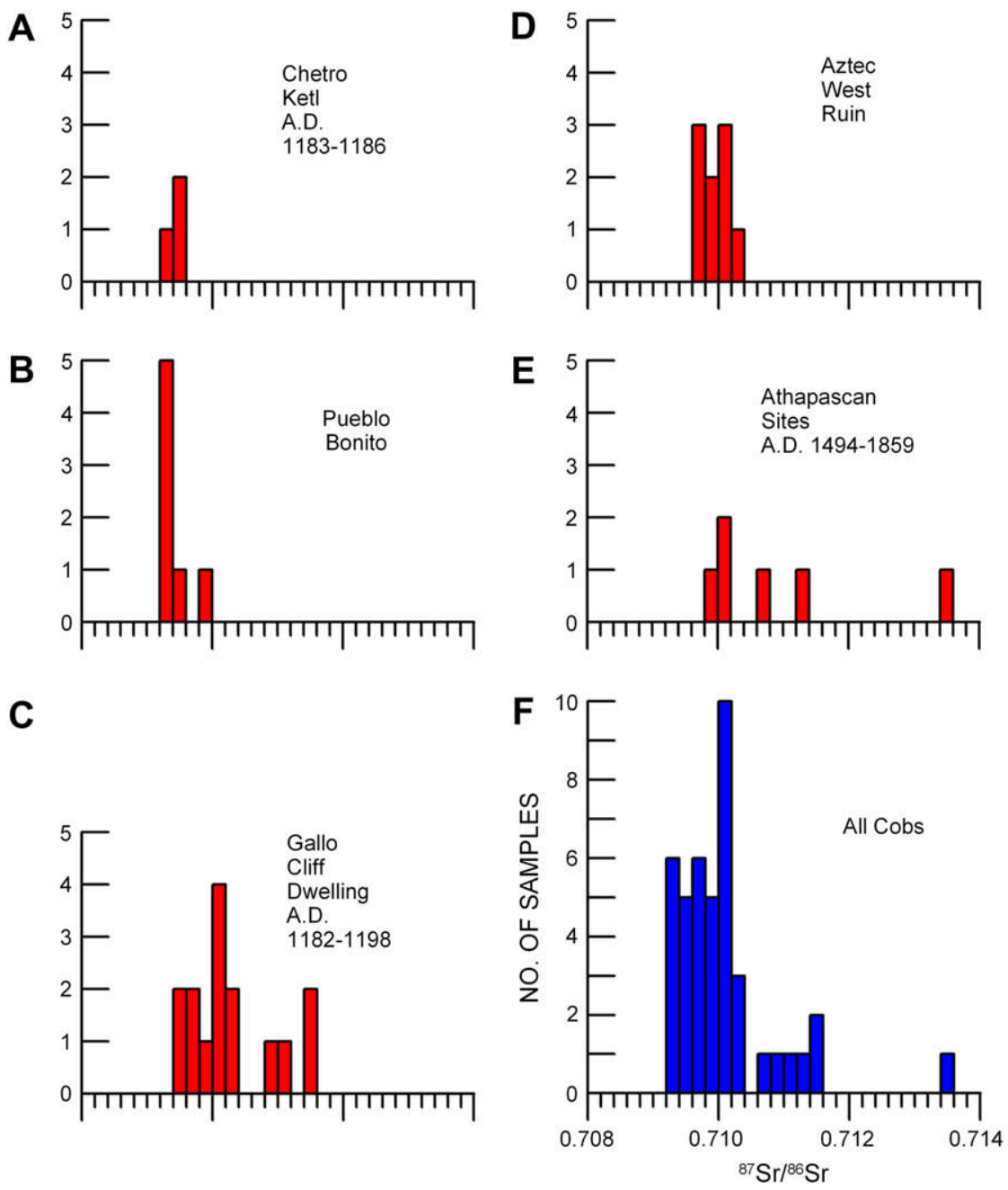

Fig. 5. ${ }^{87} \mathrm{Sr} /{ }^{86} \mathrm{Sr}$ histograms of archaeological cobs.

regions (Fig. 8B). Thus, the post-A.D. 1180 cobs could have come from any of several sites along the Upper Rio Chaco region (including Chaco Canyon itself) and from regions that lie on southwest and northwest vectors from the Canyon.

Chetro Ketl cobs have potential source areas largely confined to the Upper Rio Chaco region, including one site in Chaco Canyon (Fig. 7B). Given the distribution of potential source areas for both Chetro Ketl and Pueblo Bonito cobs, the Upper Rio Chaco region, together with the Chuska slope, may have functioned as an extended Chaco "Halo" (Doyel et al., 1984) during the pre-A.D. 1130 time period. It also may be that this sociopolitical "connection" was not completely severed by the middle-12th-century drought that resulted in the out-migration of many Anasazi from Chaco Canyon.

Athapascan-age (post-A.D. 1300) cobs have potential source areas within the Totah, Lobo Mesa, and Dinetah regions (Fig. 8C). The latter region is considered to be the traditional homeland of the Navajo.

Cobs from Aztec Ruin, most of which are associated with postA.D. 1180 timber-cutting dates, can be associated with potential source areas within the Mesa Verde and McElmo Dome regions (Fig. 7D). Only one site in the Totah region (the San Juan River floodplain near Salmon Ruin) has a soil-water chemistry that matches the Aztec Ruin cobs. This suggests the possibility of exchange between Aztec Ruin and other communities that lay to the northwest of Aztec Ruin. The soil in the Mesa Verde and McElmo Dome regions is dominated by a late Pleistocene loess deposit which extends from Blanding, Utah, to Durango, Colorado (Fig. 1) (Price et al., 1988). If this eolian deposit carries the soil-water trace-metal and isotopic signatures associated with Aztec Ruin cobs, it is possible that the source area for these cobs may lie near the Totah region.

Given that Gallo Cliff Dwelling is a Pueblo III (A.D. 1150-1300) structure, it is not surprising that the cobs found in this structure date to the late 1100s. However, it is surprising that cobs with nearly the same ages also were found in three other Downtown Chaco great houses (Pueblo Bonito, Chetro Ketl, and Kin Kletso). Given the multiplicity of potential source regions for post-A.D. 1180 cobs (Fig. 8B), we cannot determine where the cobs were grown with any degree of certainty, although the similarity of cob ages implies that they probably entered Chaco Canyon at the same time. This suggests that residents of all four Downtown Chaco structures may have been cultivating the same field area(s) within or outside the canyon, or that they were receiving maize from the same outlier community, or that a resident of Gallo Cliff Dwelling was disposing of cobs in great house structures. Of interest is the fact that the Sr of the Gallo cobs is a near-linear function of Al. This suggests that the cobs were contaminated where they were deposited by a single mineral having a nearly constant $\mathrm{Sr} / \mathrm{Al}$ ratio and an elevated ${ }^{87} \mathrm{Sr} /{ }^{86} \mathrm{Sr}$ ratio.

Provenience data exists for two of the A.D. 1180s cobs. One cob (H254/258A), dating to A.D. $1181 \pm 30$, was excavated from the floor of room 3 in Pueblo Bonito. This room, which dates to the A.D. 860s (Chaco digital initiative, 2008), was filled with sand. Thus, the cob was deposited in a very old part of Pueblo Bonito about 300 years 


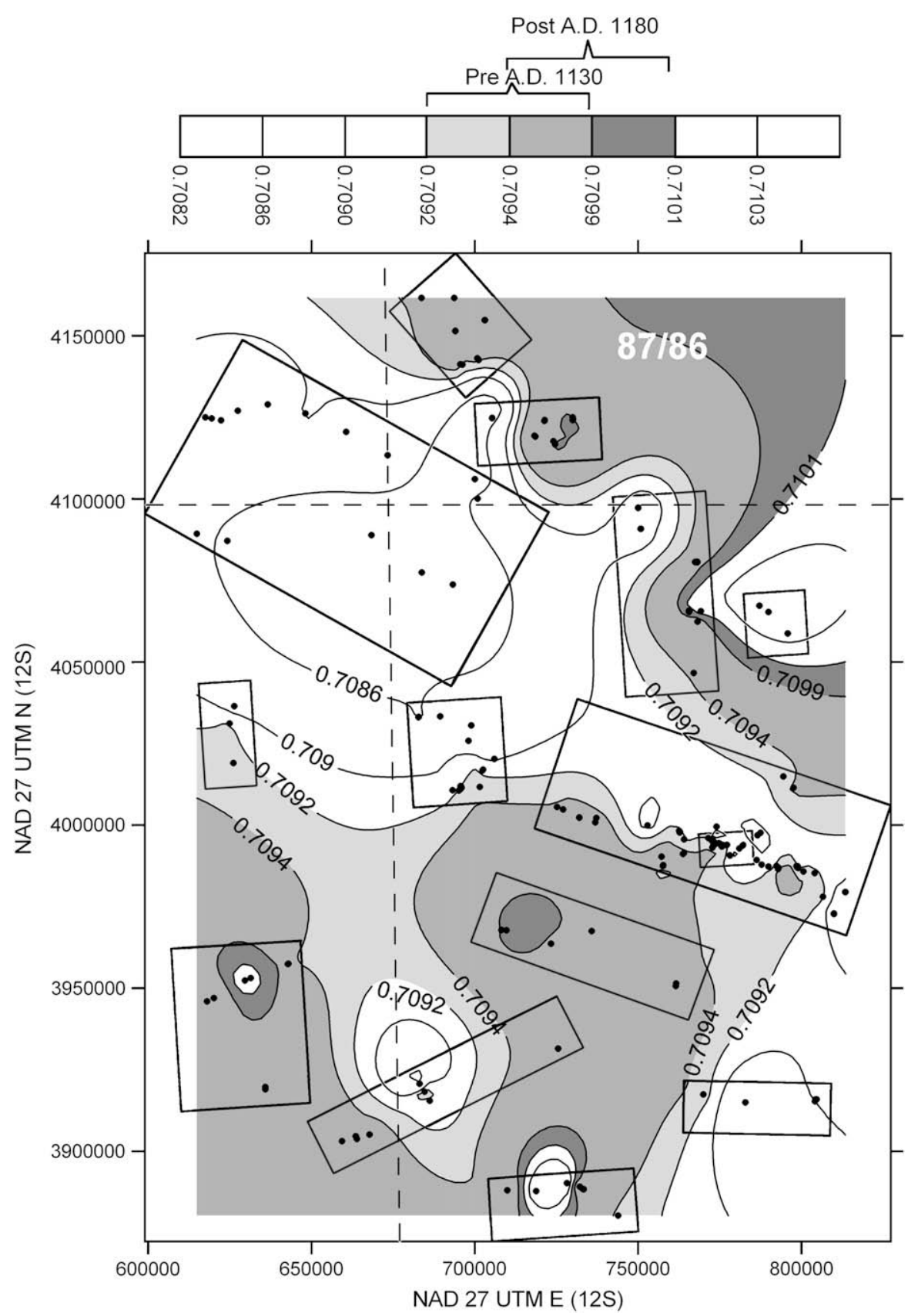

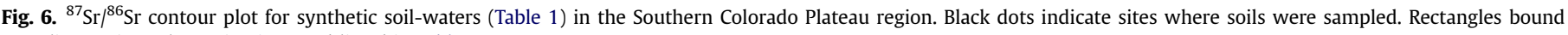
sampling regions shown in Fig. 1 and listed in Table 2.

after the room was constructed. The three cobs from Chetro Ketl, which date to A.D. 1183-1186 ( \pm 23 ), came from room 92, which has tree-ring-cutting dates that range from A.D.1033 to A.D.1070 (Chaco digital initiative, 2008). In this case, the three cobs found in this structure postdate the last phases of room construction/repair by $\sim 100$ years.

People may have occupied rooms 3 and 92 long after they were constructed; however, the simplest hypothesis is that the rooms were not occupied in the A.D. 1180s but functioned as trash receptacles. We cannot, however, determine whether the residents of Pueblo Bonito and Chetro Ketl disposed of the cobs in unoccupied rooms in those great houses or whether residents of Gallo Cliff House discarded the cobs in those great houses. One of the underlying tenets of the studies involving ${ }^{87} \mathrm{Sr} /{ }^{86} \mathrm{Sr}$ as a tracer is that the source of soluble bio-available $\mathrm{Sr}$ in the soil zone is mostly in form of windblown carbonate dust that is chemically well mixed on the scale of several kilometers (Naiman et al., 2000). We have demonstrated that ${ }^{87} \mathrm{Sr} /{ }^{86} \mathrm{Sr}$ values change systematically over the study area; however, continual expansion of the limits of the study area has increased the number of possible field sites having ${ }^{87} \mathrm{Sr} /{ }^{86} \mathrm{Sr}$ ratios that could be associated with particular groups of cobs. So, in a sense, the more soils we sample, the more choices we have in terms of cob source areas. Thus, we no longer can point to a unique solution in terms of a single source area for a particular grouping of cobs.

This study has several shortcomings, some of which may be resolved by future work. Cob contamination with soil particles prevented the application of three of the trace-metal $K_{\mathrm{D}} \mathrm{s}$; however, two of the authors of this paper (Benson and Taylor) recently have developed a method for removal of carbonate, sulfate, and silicate 
A
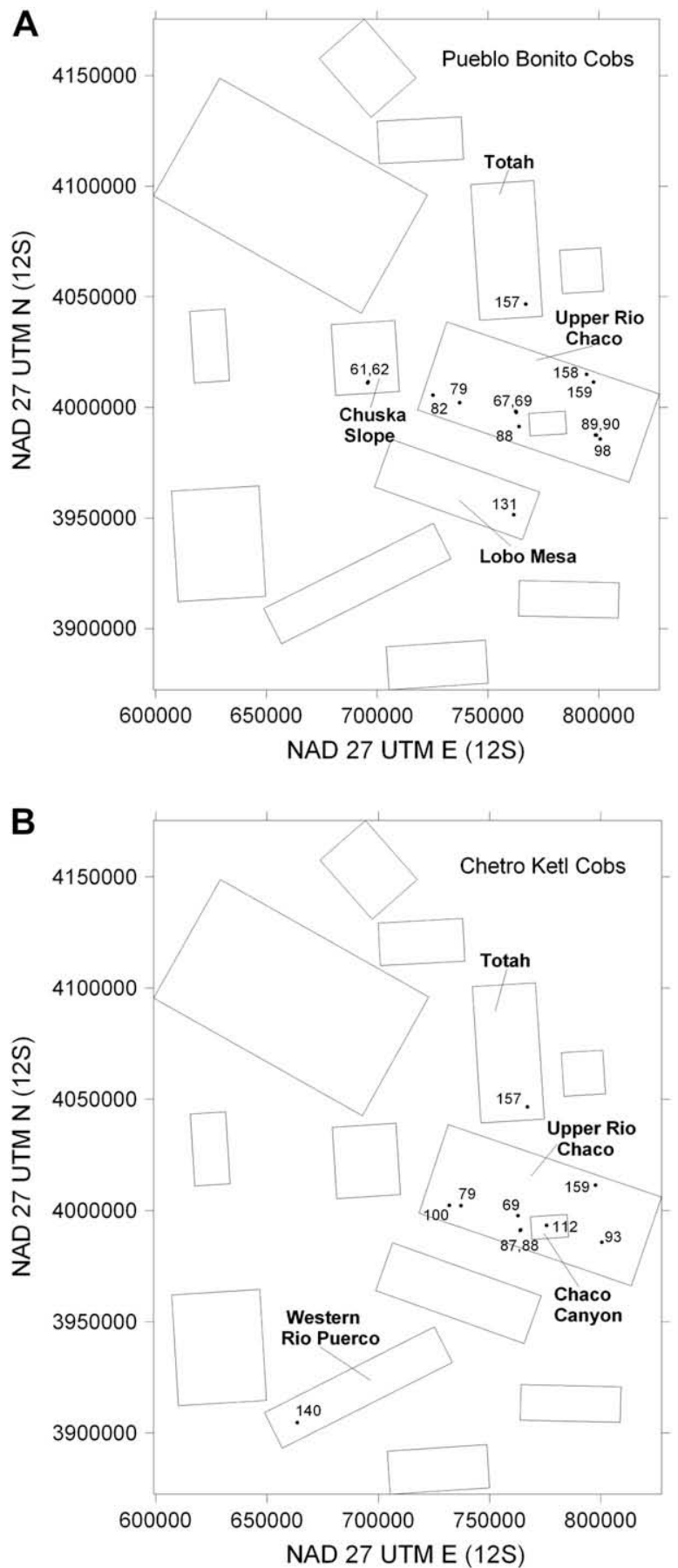
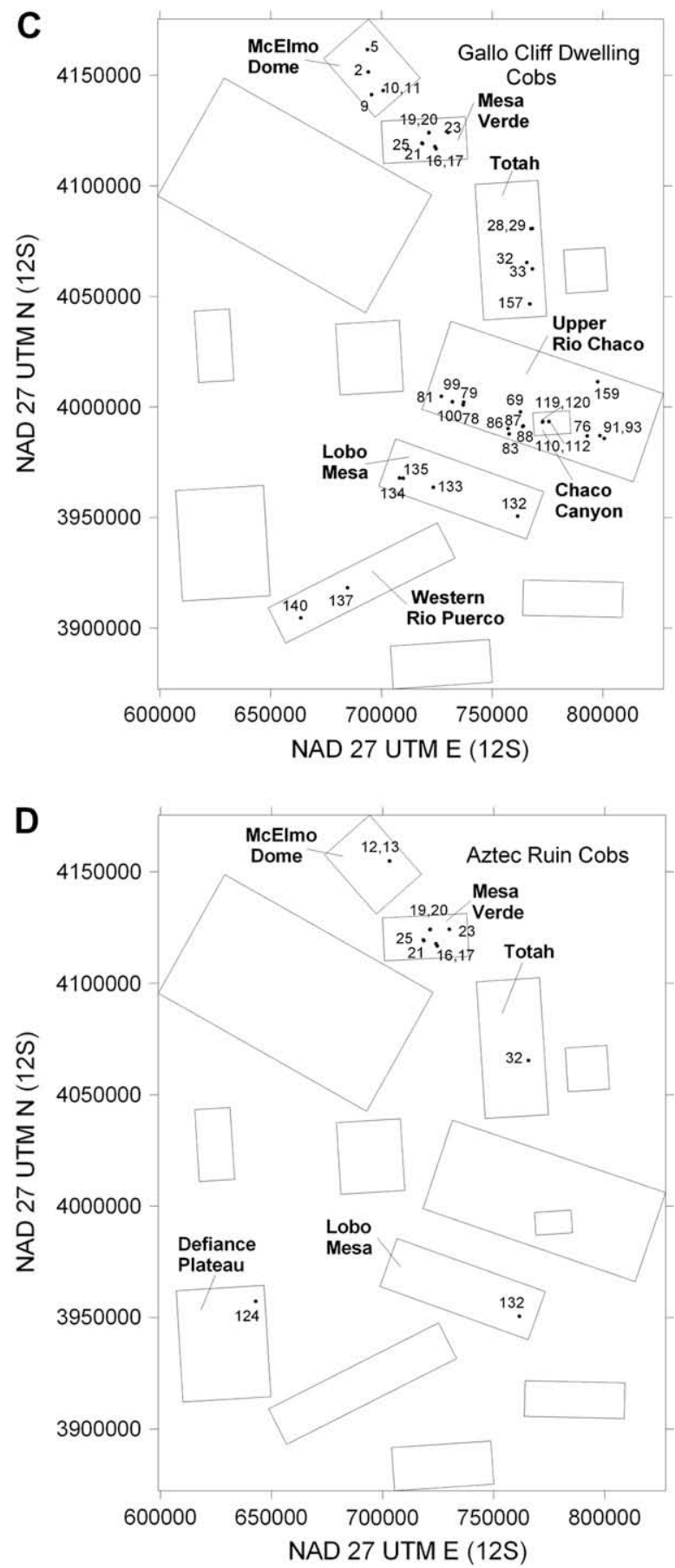

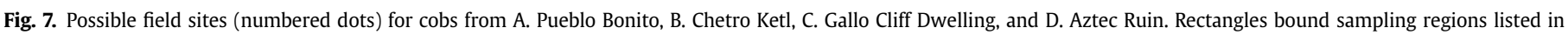
Table 2. 

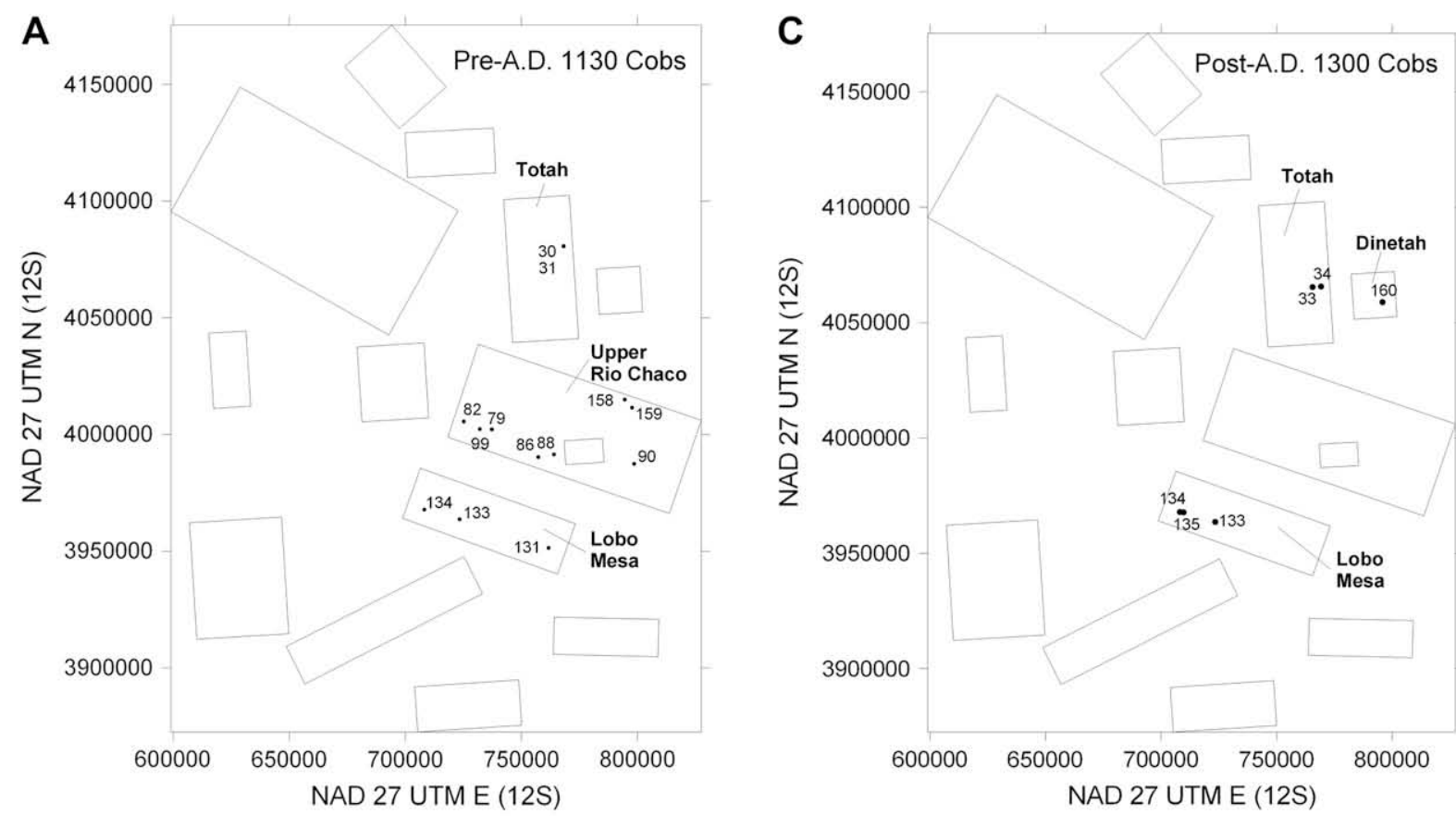

B

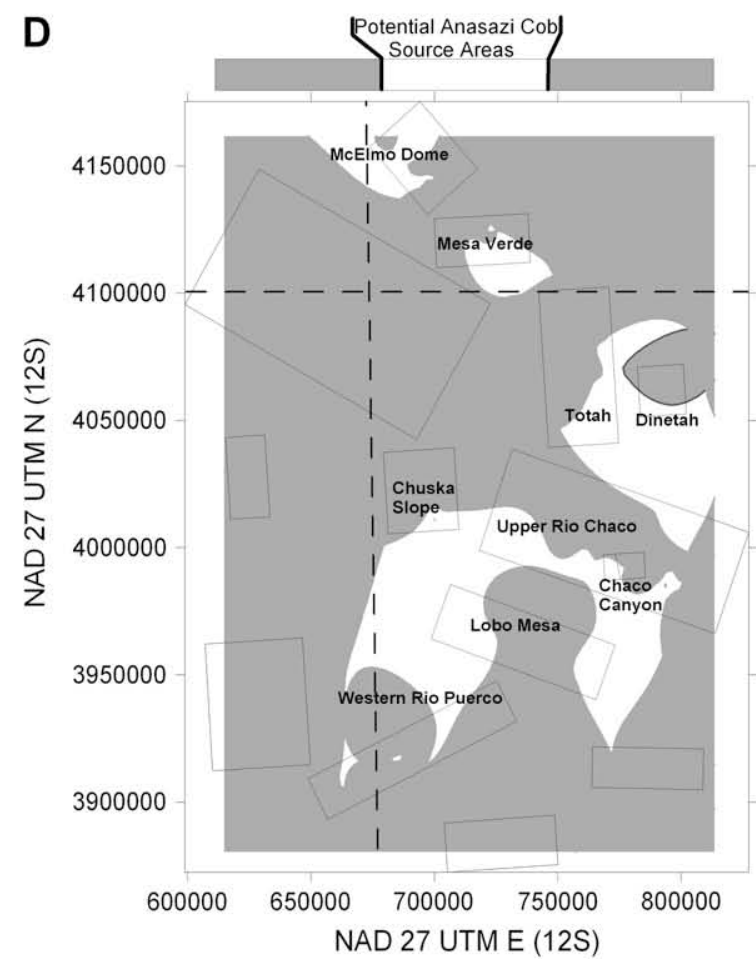

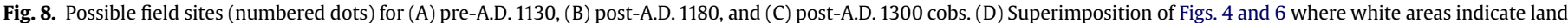
which could have been the source of Anasazi archaeological cobs.

contaminants from dirty and burnt cobs. Unfortunately, the National Park Service's Chaco Collection does not contain many Chaco Canyon archaeological cobs other than those from Gallo Cliff Dwelling and, for this reason, we may never be able to analyze a substantial number of archaeological cobs that are well-distributed in time between the founding and abandonment of Chaco. Although we have collected a large number of soil samples from the Southern Colorado Plateau region, many areas have not been sampled (Fig. 1); therefore, the existing isotopic and trace-metal contour maps (Figs. 4 and 6) do not adequately characterize the chemical compositions of soils in some areas (e.g., the area between the Dinetah and the Upper Rio Chaco). Lastly, one uncontaminated cob was found to possess a ${ }^{87} \mathrm{Sr} /{ }^{86} \mathrm{Sr}$ ratio in excess of any analyzed soil-water values. Such elevated ${ }^{87} \mathrm{Sr} /{ }^{86} \mathrm{Sr}$ ratios have been associated with Precambrian and Paleozoic rocks that lie $80-90 \mathrm{~km}$ to the east, west, and north of Chaco. These old rocks (most of which lie at relatively high elevations) may have eroded over time, providing sediments with elevated ${ }^{87} \mathrm{Sr} /{ }^{86} \mathrm{Sr}$ ratios to field sites at lower elevations. Sampling at the base of the Chuska, San Pedro, and Needles mountains could aid in confirming or refuting the 
hypothesis that these areas were field sites for archaeological cobs found in Chaco.

Future application of all four trace-metal $K_{\mathrm{D}} \mathrm{S}$ will greatly assist in the pinpointing of cob source areas. In addition, selective sampling of areas east of the Animas River, across from Aztec Ruin, and south of the San Juan River, between Bloomfield and Shiprock, may prove or disprove a local source of cobs found in Aztec Ruin. In addition, the synthetic soil-water ${ }^{87} \mathrm{Sr} /{ }^{86} \mathrm{Sr}$ database we have established for the Southern Colorado Plateau region (Fig. 1, Supplementary Table 1) can be applied by other researchers interested in sourcing a variety of organic artifacts; e.g., archaeological textiles or animal bone.

\section{Acknowledgments}

The authors would like to thank Eleanor Griffin of the USGS and Rich Friedman of the City of Farmington, New Mexico, for their help in the creation of some of the sample location maps. Terry Plowman, David Roth, Ron Antweiler, and Elizabeth Wolfe of the USGS played important roles with respect to sample preparation and trace-metal analyses. Wendy Bustard and John George of the NPS Chaco Collection provided the 30 archaeological cobs analyzed in this study. Gay Ives, Dabney Ford, and Gary Brown of the NPS and Mark Varien of the Crow Canyon Archaeological Center facilitated soil sampling of the Mesa Verde, Chaco Canyon, Aztec Ruin, and McElmo Dome areas. Tom Windes, formerly with the NPS, contributed his insights on where to sample. G. Lang Farmer at the University of Colorado-Boulder oversaw the ${ }^{87} \mathrm{Sr} /{ }^{86} \mathrm{Sr}$ analyses. The Navajo Nation's Chaco Sites Protection Program provided funding for most of the chemical analyses and field work. Any use of trade, firm, or product names is for descriptive purposes only and does not imply endorsement by the U.S. Government.

\section{Appendix. Supplementary online material}

Supplementary data associated with this article can be found, in the online version, at doi:10.1016/j.jas.2008.09.023.

\section{References}

Adams, K.R., Meegan, C.M., Ortman, S.G., Howell, R.E., Werth, L.C., Muenchrath, D.A O'Neill, M.K., Gardner, C.A.C., 2006. MAIS (Maize of American Indigenous Societies) Southwest: ear descriptions and traits that distinguish 27 morphologically distinct groups of 123 historic USDA maize (Zea mays L. spp. Mays) accessions and data relevant to archaeological subsistence models. http:// spectre.nmsu.edu (Projects and Results, Collaborative MAIS Experiment).
Benson, L., Cordell, L., Vincent, K., Taylor, H., Stein, J., Farmer, G.L., Futa, K., 2003. Ancient maize from Chacoan great houses: where was it grown? Proceedings of the National Academy of Sciences 100, 13111-13115.

Benson, L., Stein, J., Taylor, H., Friedman, R., Windes, T.C., 2006. The agricultural productivity of Chaco Canyon and the source(s) of pre-Hispanic maize found in Pueblo Bonito. In: Staller, J., Tykot, R., Benz, B. (Eds.), Histories of Maize. Elsevier, New York, pp. 289-314.

Benson, L., Petersen, K., Stein, J., 2007. Anasazi (pre-Columbian Native-American) migrations during the middle-12th and late-13th centuries - were they drought induced? Climatic Change 83, 187-213.

Benson, L.V., Taylor, H.E., Peterson, K.A., Shattuck, B.D., Ramotnik, C.A., Stein, J.R., 2008. Development and evaluation of geochemical methods for the sourcing of archaeological maize. Journal of Archaeological Science 35, 912-921.

Bickford, M.E., Wetherill, G.W., Barker, F., Lee-Hu, C.-N., 1969. Precambrian Rb-Sr chronology in the Needle Mountains, southwestern Colorado. Journal of Geophysical Research 74, 1660-1676.

Chaco digital initiative, 2008. Available at: <http://www.chacoarchive.org/>.

Cordell, L.S., Toll, H.W., Toll, M.S., Windes, T.C., 2008. Archaeological corn from Pueblo Bonito, Chaco Canyon, New Mexico: dates, contexts, sources. American Antiquity 73.

Doyel, D.E., Breternitz, C.D., Marshall, M.P., 1984. Chacoan community structure: Bis Sa'ani Pueblo and the Chaco Halo. In: Judge, W.J., Schelberg, J.D. (Eds.), Recent Research on Chaco Prehistory. Reports of the Chaco Center No. 8, pp. 37-54.

English, N.B., Betancourt, J.L., Dean, J.S., Quade, J., 2001. Strontium isotopes reveal distant sources of architectural timber in Chaco Canyon, New Mexico. Proceedings of the National Academy of Sciences 98, 11891-11896.

Judge, W.J., 1979. The development of a complex cultural ecosystem in the Chaco Basin, New Mexico. In: Linn, R.L. (Ed.), Proceedings of the First Conference on Scientific Research in the National Parks 2. U.S. Government Printing Office, Washington, D.C.

Judge, W.J., 1989. Chaco Canyon-San Juan Basin. In: Cordell, L.S., Gumerman, G.J. (Eds.), Dynamics of Southwest Prehistory. Smithsonian Institution, Washington, D.C., pp. 209-261.

Lekson, S.H., 1984. Great Pueblo Architecture of Chaco Canyon, New Mexico. University of New Mexico Press, Albuquerque.

Marshall, M.P., Doyel, D.E., Breternitz, C.D., 1982. A regional perspective on the late Bonito phase. In: Breternitz, C.D., Doyel, D.E., Marshall, M.P. (Eds.), Bis Sa'ani: A Late Bonito Phase Community on Escavada Wash, Northwest, New Mexico. Navajo Nation Papers in Anthropology No. 14. NNCRMP, Window Rock, pp. 1227-1240.

Naiman, Z., Quade, J., Patchett, P.J., 2000. Isotopic evidence for eolian recycling of pedogenic carbonate and variations in carbonate dust sources throughout the southwest United States. Geochimica et Cosmochimica Acta 64, 3099-3109.

Price, A.B., Nettleton, W.D., Bowman, G.A., Clay, V.L., 1988. Selected properties, distribution, source, and age of eolian deposits and soils of southwest Colorado. Soil Science Society of America Journal 52, 450-455.

Stein, J.R., Lekson, S.H., 1992. Anasazi ritual landscapes. In: Doyel, E.D. (Ed.), Anasazi Regional Organization and the Chaco System. Maxwell Museum of Anthropology Anthropological Papers 5. University of New Mexico, Albuquerque, pp. 87-100.

Stuiver, M., Reimer, P.J., Reimer, R.W., 2005. CALIB information and download page. http://depts.washington.edu/qil/.

Van Dyke, R.M., 1999. The Chaco connection: evaluation Bonito-style architecture in outlier communities. Journal of Anthropological Archaeology 18, 471-506.

Vivian, R.G., 1989. Kluckhohn reappraised: the Chacoan system in egalitarian enterprise. Journal of Anthropological Research 45, 101-113.

Wilcox, D., 1993. The evolution of Chacoan polity. In: Malville, J.M., Matlock, G. (Eds.), The Chimney Rock Archaeological Symposium. United States Department of Agriculture Forest Service, pp. 76-90. General Technical Report Rm-227. 